\title{
Article \\ Phenotypical Characterization and Neurogenic Differentiation of Rabbit Adipose Tissue-Derived Mesenchymal Stem Cells
}

\author{
Mária Tirpáková ${ }^{1,2, *}$, Jaromír Vašíček ${ }^{2,3}{ }^{\oplus}$, Andrea Svoradová ${ }^{3}$, Andrej Baláži ${ }^{3}$, Marián Tomka ${ }^{2}$, \\ Miroslav Bauer ${ }^{3,4}$, Alexander Makarevich ${ }^{3}$ (D) and Peter Chrenek ${ }^{2,3, *}$ \\ 1 AgroBioTech Research Center, Slovak University of Agriculture in Nitra, Tr. A. Hlinku 2, \\ 94976 Nitra, Slovakia \\ 2 Department of Biochemistry and Biotechnology, Faculty of Biotechnology and Food Sciences, \\ Slovak University of Agriculture in Nitra, Tr. A. Hlinku 2, 94976 Nitra, Slovakia; \\ jaromir.vasicek@nppc.sk (J.V.); marian.tomka@uniag.sk (M.T.) \\ 3 NPPC-Research Institute for Animal Production Nitra, Hlohovecká 2, 95141 Lužianky, Slovakia; \\ andrea.svoradova@nppc.sk (A.S.); andrej.balazi@nppc.sk (A.B.); miroslav.bauer@nppc.sk (M.B.); \\ alexander.makarevic@nppc.sk (A.M.) \\ 4 Department of Botany and Genetics, Faculty of Natural Sciences, Constantine the Philosopher University in \\ Nitra, Nábrežie Mládeže 91, 94974 Nitra, Slovakia \\ * Correspondence: maria.tirpakova@uniag.sk (M.T.); peter.chrenek@uniag.sk (P.C.); \\ Tel.: +421-37-641-4907 (M.T.); Tel.: +421-37-641-4274 (P.C.)
}

check for updates

Citation: Tirpáková, M.; Vašíček, J.; Svoradová, A.; Baláži, A.; Tomka, M.; Bauer, M.; Makarevich, A.; Chrenek, P. Phenotypical Characterization and Neurogenic Differentiation of Rabbit Adipose Tissue-Derived Mesenchymal Stem Cells. Genes 2021, 12, 431. https://doi.org/10.3390/ genes12030431

Academic Editor: M. Esther Gallardo

Received: 9 February 2021

Accepted: 15 March 2021

Published: 17 March 2021

Publisher's Note: MDPI stays neutra with regard to jurisdictional claims in published maps and institutional affiliations.

Copyright: (c) 2021 by the authors. Licensee MDPI, Basel, Switzerland. This article is an open access article distributed under the terms and conditions of the Creative Commons Attribution (CC BY) license (https:/ / creativecommons.org/licenses/by/ $4.0 /)$.

\begin{abstract}
Although the rabbit is a frequently used biological model, the phenotype of rabbit adiposederived mesenchymal stem cells (rAT-MSCs) is not well characterized. One of the reasons is the absence of specific anti-rabbit antibodies. The study aimed to characterize rAT-MSCs using flow cytometry and PCR methods, especially digital droplet PCR, which confirmed the expression of selected markers at the mRNA level. A combination of these methods validated the expression of MSCs markers (CD29, CD44, CD73, CD90 and CD105). In addition, cells were also positive for CD49f, vimentin, desmin, $\alpha$-SMA, ALDH and also for the pluripotent markers: NANOG, OCT4 and SOX2. Moreover, the present study proved the ability of rAT-MSCs to differentiate into a neurogenic lineage based on the confirmed expression of neuronal markers ENO2 and MAP2. Obtained results suggest that rAT-MSCs have, despite the slight differences in marker expression, the similar phenotype as human AT-MSCs and possess the neurodifferentiation ability. Accordingly, rAT-MSCs should be subjected to further studies with potential application in veterinary medicine but also, in case of their cryopreservation, as a source of genetic information of endangered species stored in the gene bank.
\end{abstract}

Keywords: rabbit; stem cells; adipose tissue; flow cytometry; digital droplet PCR; neural differentiation

\section{Introduction}

In the last decades, interest in research on mesenchymal stem cells (MSCs) has increased due to their specific biological features. Owing to their ability to spread and differentiate, MSCs have found widespread use, not only in regenerative medicine, but also in various disease treatment therapies, veterinary medicine and drug development, as well as stem cell banking [1-5]. The greatest advances in stem cell-based therapy so far have been achieved with MSCs isolated from bone marrow. However, many studies have reported that MSCs can be obtained from different adult tissue sources, such as skin, skeletal muscle and adipose tissue [6-8].

Compared to bone marrow, adipose tissue possesses a multitude of advantages, not only in terms of better availability, but also easier and more affordable isolation. Moreover, in the favor of adipose tissue, the stem cell yield from the adipose tissue is predominantly higher compared to that from bone marrow [9,10]. The profile of MSC surface markers differs among species. Generally, according to the International Society for Cellular Therapy (ISCT) convention, MSCs from various sources, including adipose tissue-derived stem 
cells (AT-MSCs), are described in terms of phenotypes such as $\mathrm{CD} 29^{+}, \mathrm{CD} 44^{+}, \mathrm{CD}^{+} 3^{+}$, $\mathrm{CD}^{+} 0^{+}, \mathrm{CD}_{105^{+}}$, and $\mathrm{CD} 14^{-}, \mathrm{CD} 34^{-}, \mathrm{CD}^{-} 5^{-}$[11-14]. In terms of characterization of ATMSCs' surface proteins, it is not appropriate to evaluate freshly isolated cells since no homogenous stem cell population can be obtained. It has been observed that AT-MSCs show altered expression of surface markers depending on the cell density and the number of passages $[15,16]$. Many studies are aimed at determination of AT-MSCs-specific surface markers using different techniques [8,17-19].

Stem cells derived from adipose tissue showed three lineage differentiation capacity in both in vitro and in vivo conditions. Despite their mesodermal origin, many studies have shown that they can likewise differentiate into the cells of ectodermal and endodermal origin. Generally, isolated AT-MSCs are induced to differentiation chemically using a culture medium supplemented with specific growth factors [10]. There are also novel approaches for the induction of differentiation employing the laser irradiation [10,20-23]. However, the changes in the morphology of AT-MSCs from fibroblast-like into neuron-like appearance have been associated not only with intended induction but also with cell shrinkage [24,25]. Therefore, morphological assessment alone cannot be an indicator of differentiation; thus, detection of the expression of neuronal markers is necessary. There is a wide range of neuronal markers dependent on the neuronal lineage being investigated, including glial fibrillary acidic protein (GFAP), microtubule-associated protein 2 (MAP2), nestin, neuron-specific enolase (ENO2) or $\beta$-III-tubulin [26,27].

Rabbit (Oryctolagus cuniculus) is commonly used as an experimental animal model for both human and veterinary medicine. Rabbit research is convenient due to animal body size, their ease to breed and low cost of their feeding and management [28]. Although they are comparatively larger than mice, rabbits have a shorter gestation period, which permits the use of a high number of animals and they also are phylogenetically closer to primates than rodents $[29,30]$. Thus, the objective of this study was to establish a comprehensive characterization of rabbit adipose tissue-derived stem cells, since there are only a few studies aimed at this topic. Hence, this study is mainly focused on the phenotyping of rabbit adipose tissue-derived stem cells by flow cytometry, reverse transcription-polymerase chain reaction (RT-PCR) and droplet digital PCR (ddPCR). Moreover, we examined the neurogenic differentiation potential of these cells in comparison to rabbit mesenchymal stem cells from other sources.

\section{Materials and Methods}

\subsection{Ethical Standards}

Authors proclaim that all procedures conducted in this work abide by the ethical standards of the relevant national and institutional guidelines on the care and use of laboratory animals. The treatment of the animals was approved by the Ministry of Agriculture and Rural Development of the Slovak Republic no. SK U 18016 in accordance with the ethical guidelines presented in Slovak Animal Protection Regulation, RD 377/12, which conforms to European Union Regulation 2010/63.

\subsection{Animals}

Clinically healthy rabbit females of the New Zealand White (NZW) line were used in the study. Rabbits were reared in a partially air-conditioned hall of rabbit farm of the Institute of Small Farm Animals at the NPPC-Research Institute for Animal Production Nitra, Slovakia. Housing conditions and preparation of females (hormonal stimulation and artificial insemination) were performed as described in a previous study [31]. The rabbits were fed ad libitum with a commercial feed mixture (KV, TEKRO Nitra Ltd., Nitra, Slovakia) and the water was provided ad libitum using water feeders.

\subsection{Collection and Processing of the Biological Material}

Rabbit females were humanely sacrificed at Day 23 of gestation and amniotic fluid was recovered from a withdrawn uterus and, subsequently, rabbit femurs were dissected. Pro- 
cessing of amniotic fluid and bone marrow was described in our previous studies [31-33]. Concurrently subcutaneous fat was harvested. The collected fat samples were washed with phosphate-buffered saline (PBS) (without $\mathrm{Ca}^{2+}$ and $\mathrm{Mg}^{2+}$ ions; Biowest, Riverside, MO, USA) containing 5\% penicillin/streptomycin antibiotics (Thermo Fisher Scientific, Waltham, MA, USA). Following washing, the debris (blood vessels, connective tissue, muscle tissue, etc.) was removed using scissors and tweezers. Adipose tissue was cut into small pieces and rewashed with a PBS containing antibiotics. Samples were centrifuged at $500 \times g$ for $5 \mathrm{~min}$.

\subsection{Isolation and Culture of Rabbit Stem Cells}

Adipose tissue samples were incubated at $37^{\circ} \mathrm{C}$ for about $2 \mathrm{~h}$ with collagenase type I (Sigma Aldrich, Gillingham, UK) at a concentration of $0.2 \%$. The enzymatic solution was neutralized with a culture medium and filtered through a $100 \mu \mathrm{m}$ filter to remove the undigested tissue. After filtration, the samples were centrifuged at $1200 \times g$ for $10 \mathrm{~min}$. Following centrifugation, cell pellets were resuspended in Gibco ${ }^{\mathrm{TM}} \alpha \mathrm{MEM}$ culture medium (Thermo Fisher Scientific) supplemented with 20\% fetal bovine serum (Sigma Aldrich, Gillingham, UK) and 1\% penicillin/streptomycin antibiotics (Thermo Fisher Scientific). The medium was changed every 3 days to remove non-adherent cells. Stem cells isolated from the adipose tissue (AT-MSCs) reached $90 \%$ confluency in about 6-7 days after isolation. Cells were cultured until passage 3 (P3), as previously described [34]. Isolation and culture of stem cells from the amniotic fluid (AF-MSCs) and the bone marrow (BM-MSCs) were described in previous studies [31-33]. Briefly, amniotic fluid was diluted (1:1) with a culture medium; EBM-2 basal medium (Lonza, Walkersville, MD, USA) supplemented with 20\% fetal bovine serum (Sigma Aldrich), EGM-2 SingleQuots ${ }^{\mathrm{TM}}$ Kit (Lonza), and $1 \%$ penicillin/streptomycin. Femoral bone heads were removed under sterile conditions and bone marrow was flushed using PBS (without $\mathrm{Ca}^{2+}$ and $\mathrm{Mg}^{2+}$ ions). After filtration the cell suspension was layered on a Biocoll (Biochrom, Berlin, Germany) and separated using density gradient centrifugation at $867 \times \mathrm{g}$ and $20{ }^{\circ} \mathrm{C}$ for $20 \mathrm{~min}$. Density of cell seeding was as follows: $1.2 \times 10^{4}$ cells $/ \mathrm{cm}^{2}$ for amniotic fluid and adipose tissue and $1.2-1.5 \times 10^{6}$ cells $/ \mathrm{cm}^{2}$ for the bone marrow. All types of rabbit stem cells were maintained under the same conditions at $37^{\circ} \mathrm{C}$ and a $5 \% \mathrm{CO}_{2}$ in the atmosphere.

\subsection{Culture of Human Adipose-Derived Stem Cells}

Commercially available human AT-MSCs (hAT-MSCs; C-12977, PromoCell, Heidelberg, Germany) were obtained at passage 2. Cells were cultured in Gibco ${ }^{\mathrm{TM}} \alpha \mathrm{MEM}$ culture medium (Thermo Fisher Scientific) supplemented with 20\% of fetal bovine serum (Sigma Aldrich) and $1 \%$ of antibiotic/antimycotic solution (Biowest). Cells were seeded on $75 \mathrm{~cm}^{2}$ culture flasks at a density of $1.2 \times 10^{4}$ cells $/ \mathrm{cm}^{2}$ and maintained under standard conditions at $37^{\circ} \mathrm{C}$ and a $5 \% \mathrm{CO}_{2}$ in the atmosphere.

\subsection{Population Doubling Time}

In order to determine the population doubling time (PDT), cells were counted at every passage (P1-P3) and culture time was recorded. Cells were dissociated and concentration was counted as we described in our previous study [34]. Population doubling time was counted for each passage by the growth curve using the doubling time calculator available at http:/ / www.doubling-time.com/compute.php (5 December 2020).

\subsection{Detection of Surface and Intracellular Markers Using Flow Cytometry}

To confirm the origin of rabbit BM-MSCs, AF-MSCs and AT-MSCs, the detection of the cell surface and intracellular markers was performed by an antibody immunofluorescent staining, as described in our previous studies [31,32]. The cells were double-stained using a rat anti-mouse IgG1-PE fluorochrome-conjugated secondary antibody (clone X-56; Miltenyi Biotec, Bergisch Gladbach, Germany) or goat anti-mouse IgG-FITC polyclonal antibody (STAR117F, Bio-Rad, Hercules, CA, USA). A complete list of primary antibodies with an 
indication of their reported reactivities, used in this study, is shown in Table 1. To exclude the dead cells from the analysis, samples were co-stained with dead cell marker such as 7-AAD (eBioscience, Wien, Austria). Cells were analyzed using a FACS Calibur TM device (BD Biosciences, San Jose, CA, USA) and Cell Quest Pro ${ }^{\mathrm{TM}}$ software (BD Biosciences). At least 50,000 events were analyzed for each sample. Unstained FMO (fluorescence minus one) samples were used as control samples in order to gated the positive cells according to the increased fluorescent intensity.

Table 1. List of primary antibodies used for flow cytometry.

\begin{tabular}{cccccc}
\hline Marker & Host & Reactivity & Clone & Conjugate & Company \\
\hline CD29 & mouse IgG1 & rabbit & P4G11 & FITC & Merck \\
CD34 & mouse IgG1 & human & QBEnd-10 & FITC & Thermo Fisher Scientific \\
CD44 & mouse IgG1 & rabbit & W4/86 & - & Bio-Rad \\
CD45 & mouse IgG1 & rabbit & L12/201 & - & Bio-Rad \\
CD49f & rat IgG2a & rabbit & GoH3 & AF647 & Biolegend \\
CD73 & rat IgG1 & mouse & TY /11.8 & PE-Cy7 & eBioscience \\
CD73* & mouse IgG1 & human & AD2 & FITC & eBioscience \\
CD90 & mouse IgG1 & rat & OX-7 & PE-Cy7 & BD Biosciences \\
CD90* & mouse IgG1 & human & 5E10 & FITC & BD Biosciences \\
CD105 & mouse IgG1 & rabbit & SN6 & FITC & GeneTex \\
CD105 * & mouse IgG1 & human & 266 & FITC & BD Biosciences \\
Vimentin & mouse IgG2a & human & Vim 3B4 & - & Dako Cytomation \\
$\alpha-S M A$ & mouse IgG2a & human & 1A4 & - & Dako Cytomation \\
Desmin & mouse IgG1 & human & D33 & - & Dako Cytomation \\
\hline *novel antibodies used for the detection of CD73, CD90 and CD105; $\alpha-S M A-\alpha$ smooth muscle actin.
\end{tabular}

ALDH activity was assessed using the ALDEFLUOR ${ }^{\mathrm{TM}}$ kit (STEMCELL Technologies, Vancouver, BC, Canada) and evaluated using flow cytometry. Briefly, cells were incubated with an Aldefluor substrate $\left(15 \mathrm{~min} ; 37^{\circ} \mathrm{C}\right)$ with or without the ALDH inhibitor diethylamino-benzaldehyde (DEAB) in accordance with the manufacturer's guidelines. Stained cells were analyzed by a flow cytometer (FACSCalibur, BD Biosciences). At least 25,000 cells were analyzed in each sample.

\subsection{Detection of Surface and Intracellular Markers Using Confocal Microscopy}

For the visualization of the selected rMSCs markers an immunofluorescence assay was performed. Briefly, approximately $3 \times 10^{4}$ cells from the passage 2 (P2) were resuspended in culture medium and allowed to adhere to a microscopic slide placed into a 4-well plate (NUNC) at $37{ }^{\circ} \mathrm{C}$ in a $5 \% \mathrm{CO} 2$ humidified atmosphere until reaching $80 \%$ confluency. For surface markers CD90, CD105 and pluripotent markers SOX2, NANOG, OCT4, the cells were pre-fixed using an IC Fixation Buffer (Thermo Fisher Scientific). In addition, nuclear markers SOX2, NANOG and OCT4 required permeabilization of cells with $0.1 \%$ Triton X-100. Pre-fixation and permeabilization with acetone:methanol (1:1) mixture was applied for intracellular cytoplasmic markers (vimentin, desmin, $\alpha$-SMA) and ALPL. Thereafter, the cells were gently washed with PBS and incubated with primary antibodies overnight. Cells stained for CD29, CD49f and CD73 were incubated for $20 \mathrm{~min}$, washed and postfixed with an IC Fixation Buffer. Afterward, cells were washed with PBS and incubated with an adequate secondary antibody (Table 2). Following the final cell wash with PBS, $4 \mu \mathrm{L}$ of Vectashield anti-fade mounting medium containing DAPI nuclear stain (Vector Laboratories, Burlingame, CA, USA) were pipetted on a microscope slide. Lastly, a coverslip with adhered cells was carefully placed on a microscope slide with the cell-coated side down. Stained cells were evaluated using an LSM 700 laser scanning confocal microscope (Carl Zeiss Slovakia, Bratislava, Slovak Republic). 
Table 2. List of additional primary and secondary antibodies used for confocal microscopy.

\begin{tabular}{cccccc}
\hline Marker & Host & Reactivity & Clone & Conjugate & Company \\
\hline CD49f & rat IgG1 & rabbit & GoH3 & - & Biolegend \\
Sec. Ab & goat & rat & polyclonal & FITC & Biolegend \\
ALPL & mouse & rabbit & TRA-2-49 & - & Novus Biologicals \\
SOX2 & mouse & human & 245610 & - & R\&D Systems \\
Sec. Ab & goat & mouse IgG & polyclonal & FITC & Bio-Rad \\
NANOG & goat & human & polyclonal & - & R\&D Systems \\
OCT4 & goat & human & polyclonal & - & R\&D Systems \\
Sec. Ab & donkey & goat IgG & polyclonal & FITC & Bio-Rad \\
\hline
\end{tabular}

Sec. Ab—secondary antibody; ALPL—alkaline phosphatase; SOX2—sex determining region Y—box 2; OCT4— octamer-binding transcription factor 4 .

\section{9. $R T-P C R$}

RT-PCR analyses were carried out to detect mRNA expression of specific cell surface markers. Total RNA from 3-5 $310^{6}$ rabbit stem cells was isolated using TRI Reagent ${ }^{\circledR}$ RT (Molecular Research Center, Cincinnati, OH, USA) according to the manufacturer's protocol. The purity of extracted RNA was determined by UV spectrophotometry at $260 / 280 \mathrm{~nm}$ ratio and the integrity of RNA was checked by electrophoresis in $1 \%$ agarose gel. In order to destroy contaminating DNA, before reverse transcription RNA, samples were treated with the dsDNase (Thermo Fisher Scientific). The first-strand cDNA was synthesized using Maxima H Minus First Strand cDNA Synthesis Kit (Thermo Fisher Scientific) with $1.5 \mu \mathrm{g}$ of total RNA from each sample, oligo (dT) 18 and random hexamer primers in a total volume of $20 \mu \mathrm{L}$.

The reaction was performed at $25{ }^{\circ} \mathrm{C}$ for $10 \mathrm{~min}$, then at $55{ }^{\circ} \mathrm{C}$ for $30 \mathrm{~min}$, and terminated at $85^{\circ} \mathrm{C}$ for $5 \mathrm{~min}$. A PCR was performed in $20 \mu \mathrm{L}$ reactions containing $1 \mu \mathrm{L}$ cDNA, $4 \mu \mathrm{L}$ of $5 \times$ MyTaq reaction buffer, $1 \mathrm{U}$ of MyTaq HS DNA polymerase (Bioline, Memphis, TN, USA), and 5 pmol of each primer for tested markers (Table 3) using C1000 Thermal Cycler (Bio-Rad). Rabbit $\beta$-2-microglobulin (B2M) was applied as a reference gene, and the amplification protocol for all genes was as follows: an initial denaturation and activation of Taq DNA polymerase at $95^{\circ} \mathrm{C}$ for $2 \mathrm{~min}$, followed by 35 cycles of denaturation at $95^{\circ} \mathrm{C}$ for $15 \mathrm{~s}$, annealing at $60^{\circ} \mathrm{C}$ for $15 \mathrm{~s}$ and polymerization at $72{ }^{\circ} \mathrm{C}$ for $15 \mathrm{~s}$. The final polymerization step was extended to $5 \mathrm{~min}$ at $72{ }^{\circ} \mathrm{C}$. PCR products were electrophoretically separated in $2 \%$ agarose gel in TAE buffer.

Table 3. Nucleotide sequences and size of RT-PCR products.

\begin{tabular}{|c|c|c|c|c|}
\hline Gene & Product Size (bp) & Forward Primer & Reverse Primer & Reference \\
\hline CD29 & 287 & 5'-AGAATGTCACCAACCGTAGCA-3' & 5'-CACAAAGGAGCCAAACCCA-3' & [35] \\
\hline CD44 & 112 & 5'-TCATCCTGGCATCССТСТTG-3' & 5'-CCGTTGCCATTGTTGATCAC-3' & [11] \\
\hline CD73 & 170 & 5'-СТССТТТССТСТСАААТССАG-3' & 5'-GTCCACGCCCTTCACTTTC-3' & [35] \\
\hline CD90 & 293 & $5^{\prime}$-CTGCTGCTGCTCTCACTGTC-3' & 5'-ACAGAAGCAGCTTTGGGAAA-3' & [31] \\
\hline CD105 & 109 & $5^{\prime}$-TGACATACAGCACCAGCCAG-3' & 5'-AGCTCTGACACCTCGTTTGG-3' & [11] \\
\hline $\mathrm{B} 2 \mathrm{M}$ & 118 & $5^{\prime}$-ATTCACGCCCAATGATAAGG-3' & $5^{\prime}$-ATCCTCAGACCTCCATGCTG-3' & [31] \\
\hline CD34 & 206 & $5^{\prime}$-TTTCCTCATGAACCGTCGCA-3' & 5'-CGTGTTGTCTTGCGGAATGG-3' & [31] \\
\hline CD45 & 262 & 5'-TACTCTGCCTCCCGTTG-3' & 5'-GCTGAGTGTCTGCGTGTC-3' & [35] \\
\hline $\begin{array}{c}\text { ST3GAL2 } \\
\text { (SSEA-4) }\end{array}$ & 126 & 5'-CTGGGAGAATAACCGGTACG-3' & 5'-GCTCAGTTGCCTCGGTAGAC-3' & [33] \\
\hline $\begin{array}{c}\text { ALPL } \\
\text { (MSCA-1) }\end{array}$ & 137 & 5'-CCCTCATGTGATGGCTTACG-3' & 5'-CTCAGAACAGGACGCTCAGG-3' & [33] \\
\hline NANOG & 122 & 5'-GCCAGTCGTGGAGTAACCAT-3' & 5'-CTGCATGGAGGACTGTAGCA-3' & [31] \\
\hline OCT4 & 149 & 5'-GAGGAGTCCCAGGACATGAA-3' & 5'-GTGGTTTGGCTGAACACCTT-3' & [31] \\
\hline SOX2 & 152 & 5'-CAGCTCGCAGACCTACATGA-3' & 5'-TGGAGTGGGAGGAAGAGGTA-3' & [31] \\
\hline ALDH & 135 & 5'-CTGGGAAAAGCAACCTGAAG-3' & 5'-AACACTGGCCCTGATGGTAG-3' & NM_001082013.1 ${ }^{1}$ \\
\hline
\end{tabular}

${ }^{1}$ NCBI Reference Sequence; B2M- $\beta$ - 2 microglobulin; ST3GAL2—ST3 $\beta$-galactoside $\alpha$-2,3-sialytransferase 2; SSEA-4—stage-specific embryonic antigen 4; ALPL—alkaline phosphatase; MSCA-1—mesenchymal stromal cell antigen-1; SOX2—sex determining region Y—box 2; OCT4 — octamer-binding transcription factor 4; ALDH—aldehyde dehydrogenase. 


\subsection{Digital Droplet PCR}

In order to quantify the expression of chosen markers at the mRNA level, we used a novel method of digital droplet PCR (ddPCR). The reaction mixture was prepared according to the manufacturer's protocol and contained $10 \mu \mathrm{L}$ of QX200 ${ }^{\mathrm{TM}}$ ddPCR ${ }^{\mathrm{TM}}$ EvaGreenSupermix (Bio-Rad), $1 \mu \mathrm{L}$ of cDNA, $0.5 \mu \mathrm{L}$ of primers and was filled to the final volume of $20 \mu \mathrm{L}$ with ultrapure water. Thereafter, prepared suspension was divided into individual tubes. To form droplets, $20 \mu \mathrm{L}$ of the reaction mixture were mixed with $70 \mu \mathrm{L}$ of oil, and samples were afterward pipetted onto a droplet generation cartridge DG8 $8^{\mathrm{TM}}$ plate for the QX200 ${ }^{\mathrm{TM}}$ Droplet Generation Oil for EvaGreen system (Bio-Rad). The loaded cartridge was covered with a DG8 Gasket and placed into the QX200 Droplet Generator. Once the droplet generation is completed, droplets were pipetted onto a PCR 96-well plate (Bio-Rad) and sealed prior to the PCR reaction. The sealed plate was placed into a T100 thermal cycler (Bio-Rad), where the PCR reaction took place under the following conditions: initial denaturation and activation of hot-start DNA polymerase at $95^{\circ} \mathrm{C}$ for $2 \mathrm{~min}$ followed by 40 cycles of denaturation at $95^{\circ} \mathrm{C}$ for $15 \mathrm{~s}$, annealing at $60^{\circ} \mathrm{C}$ for $15 \mathrm{~s}$ and extension at $72{ }^{\circ} \mathrm{C}$ for $15 \mathrm{~s}$. When PCR amplification is complete, droplets were read using the QX200 Droplet Reader (Bio-Rad), where the individual droplets were evaluated separately based on the fluorescence signal. The results were evaluated using Quanta Soft version 1.7.4.0917 (Bio-Rad). To achieve the most accurate results, only samples containing at least 12,000 droplets were used for quantification. The results were expressed as a ratio of the number of positive droplets to the total number of droplets in the sample.

\subsection{Neurogenic Differentiation}

To confirm the potential of neurogenic differentiation of rabbit stem cells, the cells at P2 were seeded with density of $1.0 \times 10^{4}$ cells per $\mathrm{cm}^{2}$ and were cultured in a standard culture medium supplemented with $20 \%$ of FBS and $1 \%$ antibiotics. After reaching about $80 \%$ confluency, cells were detached as described above and reseeded on $75 \mathrm{~cm}^{2}$ tissue culture flasks with a density of $1.0 \times 10^{4}$ cells per $\mathrm{cm}^{2}$. After $48 \mathrm{~h}$, cells became subconfluent (about 80\%), culture medium was discarded, cells were washed with PBS and the medium was replaced with a mesenchymal stem cell neurogenic differentiation medium (PromoCell, Heidelberg, Germany). Differentiation of rabbit stem cells into neurogenic lineage was performed according to the manufacturer's instructions under standard growth condition $\left(37^{\circ} \mathrm{C} ; 5 \% \mathrm{CO}_{2}\right)$. The medium was changed after $48 \mathrm{~h}$. After 3 days of induction, cells were detached and used for further analyses. In addition, the typical three-lineage differentiation potential of these cells was analyzed (Appendix A).

\subsection{2. $R T-q P C R$}

Total RNA isolation from rabbit stem cells (rBM-MSCs, rAF-MSCs, rAT-MSCs) and cDNA synthesis were done as described above. A PCR was performed in $20 \mu \mathrm{L}$ parallel reactions containing $1 \mu \mathrm{L}$ of cDNA, $10 \mu \mathrm{L}$ of DyNAmo Flash SYBR Green PCR mix (Thermo Fisher Scientific), and 5 pmol of each primer for MAP2, ENO2, and $\beta$-2-microglobulin (B2M), as a reference gene (Table 4) in Rotor-Gene 6000 device (Corbett Research, Sydney, Australia). The amplification protocol was the following: an initial denaturation and activation of Taq DNA polymerase at $95^{\circ} \mathrm{C}$ for $7 \mathrm{~min}$ followed by 40 cycles of $95^{\circ} \mathrm{C}$ for $10 \mathrm{~s}$, $60{ }^{\circ} \mathrm{C}$ for $10 \mathrm{~s}$ and $72{ }^{\circ} \mathrm{C}$ for $10 \mathrm{~s}$. To check the specificity of PCR products, a melting curve analysis within a temperature range of $72-95^{\circ} \mathrm{C}$ as well as electrophoresis in $2 \%$ agarose gel were performed. The standard curves were generated for all genes using a serial dilution of template cDNA. Relative quantification of MAP2 and ENO2 expression to reference B2M gene was calculated using the threshold $\left(C_{T}\right)$ values and PCR reaction efficiencies according to Pfaffl [36]. In respect to the hAT-MSCs, the same protocol was applied using primers specified in Table 4. 
Table 4. Nucleotide sequences and size of RT-qPCR products.

\begin{tabular}{|c|c|c|c|c|c|}
\hline & Gene & $\begin{array}{l}\text { Product Size } \\
\text { (bp) }\end{array}$ & Forward Primer & Reverse Primer & Reference \\
\hline \multirow{3}{*}{ rMSCs } & $\mathrm{ENO} 2$ & 128 & $5^{\prime}$ - ACACACTCAAGGGGGTCATC $-3^{\prime}$ & 5' - GTCGATGGCTTCCTTTACCA -3' & XM_002712914.3 ${ }^{1}$ \\
\hline & MAP2 & 161 & $5^{\prime}$ - CTCACCATGTTCCTGGAGGT $-3^{\prime}$ & $5^{\prime}$ - GGAGGAGACGTTGCTGAGTC $-3^{\prime}$ & XM_017343068.1 ${ }^{1}$ \\
\hline & $\mathrm{B} 2 \mathrm{M}$ & 118 & 5'-СТССТTТССТСТСАААТCСAG-3' & 5'-GTCCACGCCCTTCACTTTC-3' & [31] \\
\hline \multirow{3}{*}{ hMSCs } & hENO2 & 238 & $5^{\prime}$ - GGAGAACAGTGAAGCCTTGG $-3^{\prime}$ & $5^{\prime}$ - GGTCAAATGGGTCCTCAATG $-3^{\prime}$ & [37] \\
\hline & hMAP2 & 97 & $5^{\prime}$ - AGTTCCAGCAGCGTGATG - $3^{\prime}$ & 5'- CATTCTCTCTTCAGCCTTCTC - -3' & [37] \\
\hline & hACT & 125 & $5^{\prime}$ - CCTGGCGTCGTCATTAGTG $-3^{\prime}$ & $5^{\prime}$-TCAGTCCTGTCCATAATTAGTCC-3' & [37] \\
\hline
\end{tabular}

${ }^{1}$ NCBI Reference Sequence; rMSCs—rabbit mesenchymal stem cells; hMSCs—human mesenchymal stem cells; ENO2-neuron-specific enolase; MAP2 - microtubule-associated protein $2 ; \mathrm{B} 2 \mathrm{M}-\beta-2$ microglobulin; hACT— $\beta$-actin.

\subsection{Fluorescent Assessment of Neurodifferentiation}

Successful neurodifferentiation was confirmed based on the chosen markers microtubuleassociated protein 2 (MAP2) and neuron-specific enolase (ENO2) using confocal microscopy. Cell culture was assessed after three days of induction of differentiation into neurogenic lineage: starting since overnight incubation with a MAP2 primary antibody (Clone BB7, Creative Diagnostics, Shirley, NY, USA) or ENO2 (Clone NSE47, Enzo Life Sciences, Farmingdale, NY, USA), followed by washing and consequent incubation with a goat anti-mouse IgG-FITC secondary antibody (STAR117F, Bio-Rad).

\subsection{Statistical Analysis}

The results were evaluated with the descriptive statistics or a Student's t-test (for RT-qPCR) using the SigmaPlot software (Systat Software Inc., Erkrath, Germany). The values are expressed as the means $\pm \mathrm{SD}$.

\section{Results}

\subsection{Morphology and Proliferation of Rabbit AT-MSCs}

Immediately after seeding, the cells with round shape were observed. After $24 \mathrm{~h}$ of plating, cells started to adhere to tissue culture flasks and their morphology changed into spindle-shaped (Figure 1A). The medium was replaced every 2 days to remove nonadherent cells. On the approximately third day, cells began to cluster into small colonies, proliferated rapidly and reached about $50-60 \%$ confluency (Figure 1B,C). After 6-7 days the cells reached $90 \%$ confluency and the culture consisted of a homogenous monolayer of fibroblast-like cells (Figure 1D). PDT was calculated basing on the cell number counted after detachment and the culture period. The average PDT for rAT-MSCs in our study was $37.45 \pm 1.32 \mathrm{~h}$.

\subsection{Detection of the Expression of Surface and Intracellular Markers Using Flow Cytometry}

Analysis of the phenotype of rMSCs showed high positivity of CD29, CD44, CD49f as well as intracellular markers-vimentin, desmin and $\alpha$-smooth muscle actin ( $\alpha$-SMA). The expression of CD73, CD90, and CD105 markers was not of the expected percentage, therefore, these antibodies were substituted by available alternatives of higher affinity. New anti-human antibodies for detection of CD73, CD90 and CD105 determined higher expression, especially for the surface marker CD90. High expression (over 90\%) of CD73, CD90 and CD105 was confirmed in the case of hAT-MSCs. The activity of aldehyde dehydrogenase (ALDH) was highly positive (more than 70\%) only in rAT-MSCs, rBMMSCs and also in hAT-MSCs. Markers of hematopoietic lineage (CD34 and CD45), used as a negative control, were not expressed by any type of rMSCs. The expression was represented as the mean $(\%) \pm \mathrm{SD}$, separately for each marker (Table 5). 

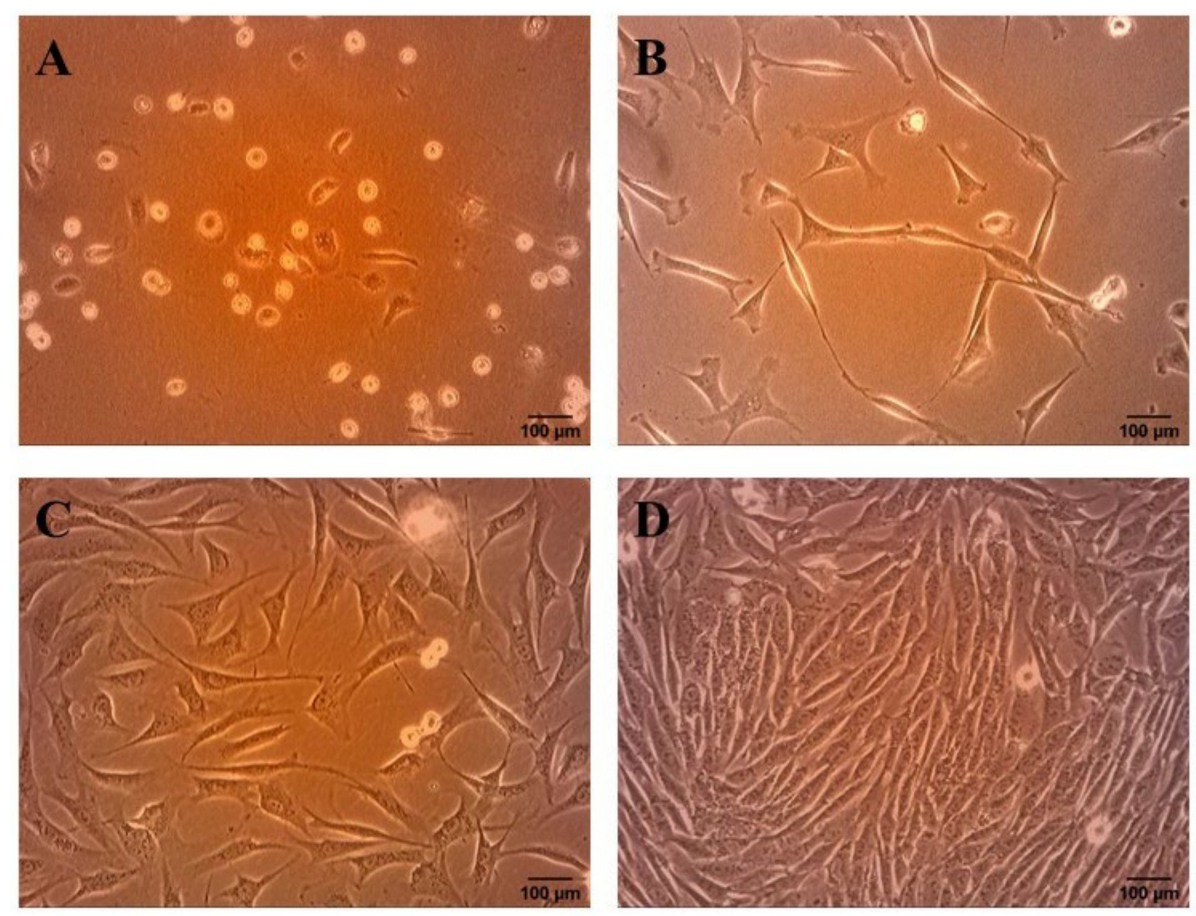

Figure 1. Morphological changes in rAT-MSCs during the culture. (A): Cells started to adhere to culture flasks $24 \mathrm{~h}$ after seeding; (B): the cells began to cluster into small colonies $72 \mathrm{~h}$ in culture; (C): the cells reached confluency approximately 50-60\% on the 5th day; (D): cell culture consisted of a homogenous monolayer of fibroblast-like cells on the 7th day after isolation (scale bar $=100 \mu \mathrm{m}$ ).

Table 5. Detection of the expression of markers using flow cytometry.

\begin{tabular}{ccccc}
\hline & \multicolumn{4}{c}{ Percentage of Positive Cells \% } \\
\cline { 2 - 5 } & rAT-MSCs & rBM-MSCs & rAF-MSCs & hAT-MSCs \\
\hline CD29 & $92.12 \pm 6.65$ & $89.50 \pm 8.03[33]$ & $96.0 \pm 5.7[32]$ & $98.98 \pm 0.59$ \\
CD34 & $1.42 \pm 0.67$ & $0.78 \pm 0.44[33]$ & $0.37 \pm 0.2[32]$ & 0.77 \\
CD44 & $97.15 \pm 1.45$ & $89.08 \pm 8.44[33]$ & $93.7 \pm 2.3[32]$ & NT \\
CD45 & $1.13 \pm 0.40$ & $4.52 \pm 2.99[33]$ & $1.65 \pm 1.1[32]$ & NT \\
CD49f & $98.92 \pm 0.86$ & $79.32 \pm 12.63$ & $96.68 \pm 1.61$ & $77.90 \pm 10.18$ \\
CD73 & $4.10 \pm 0.02$ & $3.54 \pm 1.83[33]$ & $7.93 \pm 5.0[32]$ & NT \\
CD73 & $60.50 \pm 7.37$ & $73.75 \pm 21.16$ & $27.23 \pm 16.54$ & $98.58 \pm 0.32$ \\
CD90 & $10.21 \pm 0.07$ & $8.74 \pm 4.39[33]$ & $15.6 \pm 4.0[32]$ & NT \\
CD90 * & $95.97 \pm 3.17$ & $98.23 \pm 2.09$ & $70.77 \pm 16.55$ & $98.97 \pm 0.47$ \\
CD105 & $4.60 \pm 0.86$ & $2.03 \pm 1.73[33]$ & $0.56 \pm 0.4[32]$ & NT \\
CD105 & $38.83 \pm 4.30$ & $73.45 \pm 10.96$ & $11.50 \pm 3.30$ & $94.44 \pm 1.93$ \\
Vimentin & $85.08 \pm 11.43$ & $97.84 \pm 3.80[33]$ & $91.9 \pm 4.7[32]$ & NT \\
$\alpha$-SMA & $86.26 \pm 10.15$ & $98.75 \pm 1.19[33]$ & $89.0 \pm 9.0[32]$ & NT \\
Desmin & $75.29 \pm 17.09$ & $50.12 \pm 11.37[33]$ & $85.1 \pm 9.9[32]$ & NT \\
ALDH & $74.63 \pm 13.61$ & $70.60 \pm 21.38$ & $31.13 \pm 8.11$ & $75.56 \pm 5.32$ \\
\hline
\end{tabular}

* novel antibodies used for the detection of CD73, CD90 and CD105; $\alpha$-SMA- $\alpha$ smooth muscle actin; ALDHaldehyde dehydrogenase; rAT-MSCs—rabbit adipose tissue-derived mesenchymal stem cells; rBM- MSCs—rabbit bone marrow mesenchymal stem cells; rAF-MSCs—rabbit amniotic fluid mesenchymal stem cells; hAT-MSCshuman adipose tissue-derived mesenchymal stem cells; NT-not tested.

\subsection{Detection of Surface and Intracellular Markers Using Confocal Microscopy}

To confirm the phenotype, confocal microscopy proved the expression of all tested surface markers (Figure 2) and intracellular markers (vimentin, desmin and $\alpha$-SMA; Figure 3) in both rabbit and human AT-MSCs. Moreover, immunofluorescent staining of rAT-MSCs showed positive expression of the selected pluripotent markers NANOG, OCT4 and SOX2 (Figure 4). 


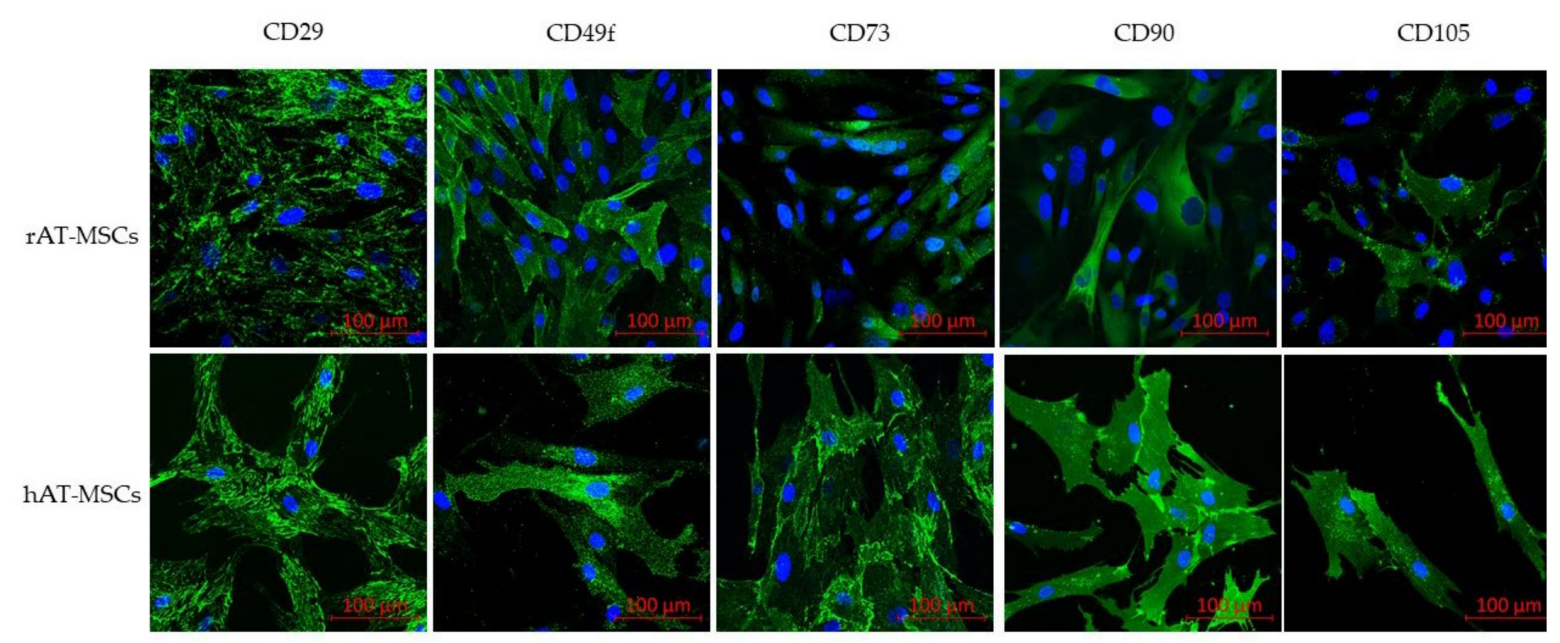

Figure 2. Immunofluorescence of selected surface markers of rabbit (rAT-MSCs) and human (hAT-MSCs) samples (scale bar $=100 \mu \mathrm{m})$.
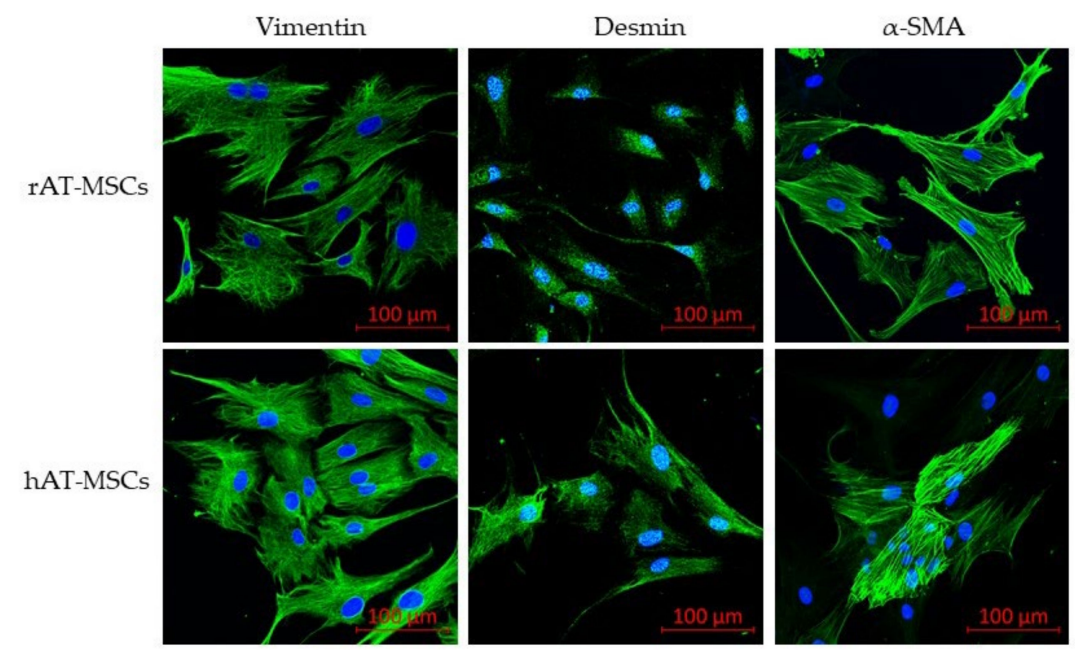

Figure 3. Immunofluorescence of selected intracellular markers of rabbit (rAT-MSCs) and human (hAT-MSCs) samples; $\alpha$-SMA— $\alpha$ smooth muscle actin; (scale bar $=100 \mu \mathrm{m}$ ).

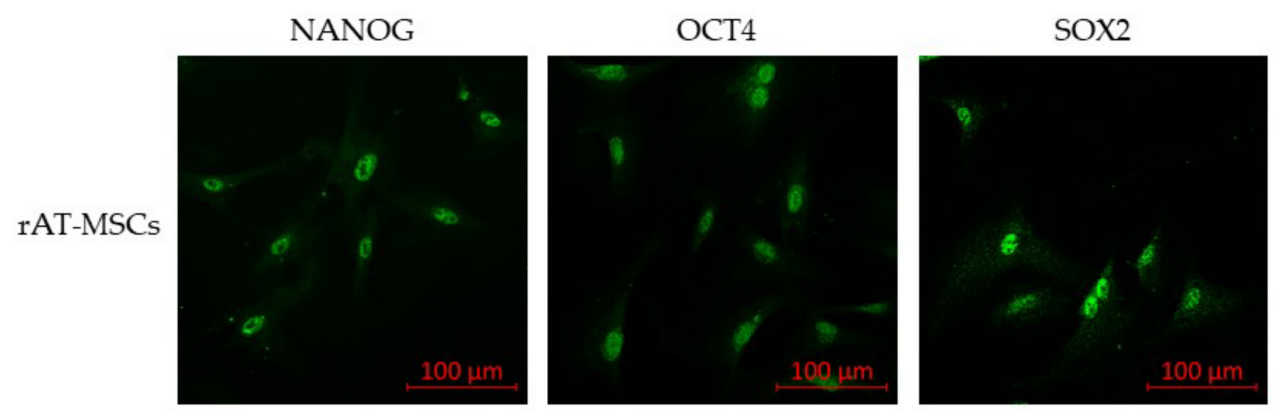

Figure 4. Immunofluorescence of selected pluripotent markers of rabbit (rAT-MSCs) samples; SOX2-sex determining region $\mathrm{Y}$-box 2; OCT4-octamer-binding transcription factor 4; (scale bar $=100 \mu \mathrm{m})$.

\section{4. $R T-P C R$}

The expression of surface and pluripotency markers was assessed at the mRNA level using the RT-PCR method. The following cell surface markers were examined: CD29, CD44, CD73, CD90, CD105, CD146, CD166, CD34 and CD45. Cell pluripotency markers (NANOG, OCT4 and SOX2) and other stem cell-specific markers (ST3GAL2 and ALDH) were also monitored. The rabbit $\beta-2$ microglobulin (B2M) was used as a reference gene. The results 
of RT-PCR analyses confirm that rMSCs express all CD surface markers characteristic for MSCs (CD29, CD44, CD73, CD90 and CD105). The markers of the hematopoietic line (CD34 and CD45) were not expressed in tested samples (Figure 5). Rabbit AT-MSCs also expressed pluripotent markers OCT4 and SOX2, and a weak signal was recorded also for NANOG. The presence of ST3GAL2 and ALDH markers was also verified (Figure 6).

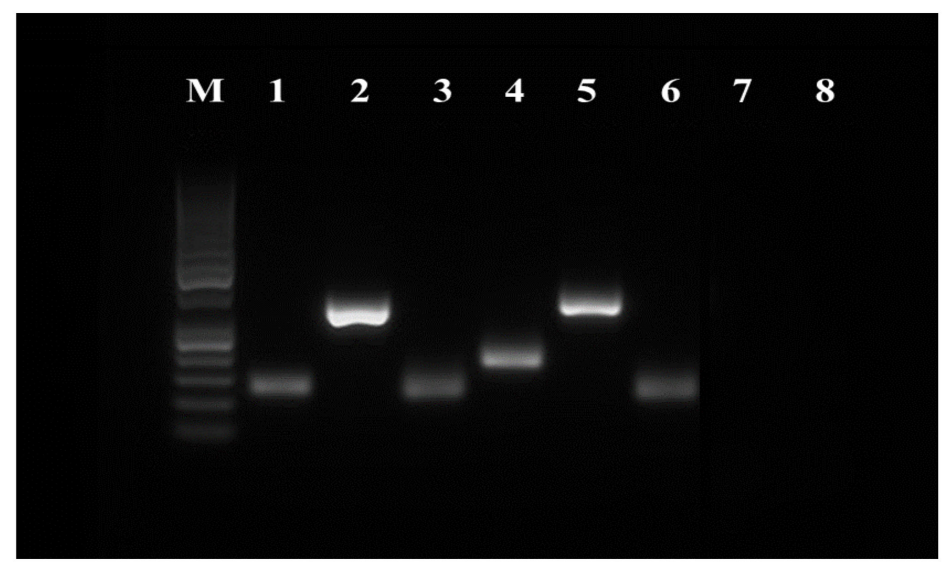

Figure 5. RT-PCR analysis of the expression of rAT-MSCs surface markers. Lane M-50 bp DNA ladder (Thermo Fisher Scientific, USA); lane 1-B2M (control); lane 2-CD29; lane 3-CD44; lane 4-CD73; lane 5-CD90; lane 6-CD105; lane 7-CD34; lane 8-CD45.

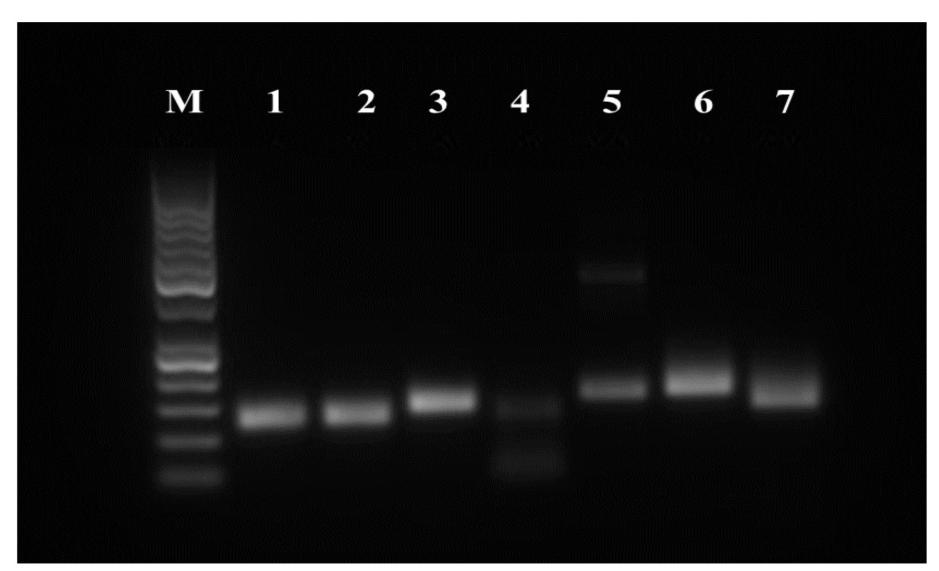

Figure 6. RT-PCR analysis of the expression of rAT-MSCs pluripotency markers. Lane M-50 bp DNA ladder (Thermo Fisher Scientific, USA); lane 1-B2M (control); lane 2-ST3GAL2; lane 3-ALPL; lane 4-NANOG; lane 5-OCT4; lane 6-SOX2; lane 7-ALDH.

\subsection{Droplet Digital PCR}

In each sample, an average of 12,000 droplets were evaluated. The results of the analyses were expressed as the average percentage of positive droplets \pm SD. Results are summarized in Table 6. Results obtained from ddPCR indicate high expression of all selected markers. Marker of hematopoietic lineage (CD45), used as a negative control, was not expressed in rMSCs. 
Table 6. Expression of surface markers using ddPCR.

\begin{tabular}{cccc}
\hline & \multicolumn{3}{c}{ Percentage of Positive Droplets \% } \\
\cline { 2 - 4 } & rAT-MSCs & rBM-MSCs & rAF-MSCs \\
\hline CD29 & $90.3 \pm 6.7$ & $94.6 \pm 5.4$ & $89.1 \pm 7.7$ \\
CD44 & $99.5 \pm 0.8$ & $89.9 \pm 8.7$ & $89.6 \pm 12.6$ \\
CD45 & $0.0 \pm 0.0$ & $0.1 \pm 0.0$ & $0.0 \pm 0.0$ \\
CD73 & $60.7 \pm 25.5$ & $42.1 \pm 15.4$ & $25.7 \pm 16.8$ \\
CD90 & $99.9 \pm 0.0$ & $47.9 \pm 8.6$ & $58.3 \pm 7.4$ \\
CD105 & $55.8 \pm 22.2$ & $50.4 \pm 28.0$ & $16.1 \pm 10.5$ \\
\hline
\end{tabular}

rAT-MSCs-rabbit adipose tissue-derived mesenchymal stem cells; rBM-MSCs-rabbit bone marrow mesenchymal stem cells; rAF-MSCs—rabbit amniotic fluid mesenchymal stem cells.

\subsection{Neurodifferentiation of Rabbit Stem Cells}

3.6.1. RT-qPCR

Analysis of neural gene expression using quantitative real-time PCR was performed to evaluate the differentiation of rMSCs induced with a specific neuronal differentiation culture medium. The results displayed a significantly higher level of gene expression in differentiated cells for both markers ENO2 and MAP2 already on the 3rd day of induction (Figure 7).
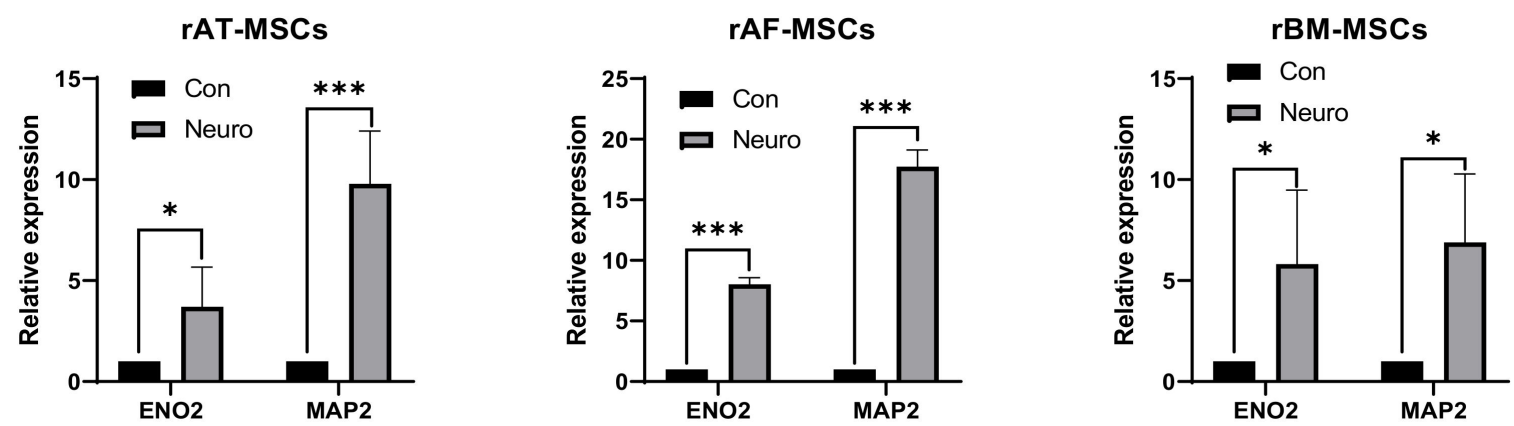

Figure 7. Results of neural marker gene expression using RT-qPCR. ${ }^{*} p<0.05$; ${ }^{* *} p<0.001$; Con—control (non-induced sample), Neuro-neurodifferentiated sample; rAT-MSCs—rabbit adipose tissue-derived mesenchymal stem cells; rAFMSCs—rabbit amniotic fluid mesenchymal stem cells; rBM-MSCs—rabbit bone marrow mesenchymal stem cells; ENO2neuron-specific enolase; MAP2-microtubule-associated protein 2.

In the case of hAT-MSCs, enhanced expression of ENO2 was not noticed in the group of differentiated cells. In contrast, the expression of the MAP2 marker was significantly increased in the group of differentiated cells (Figure 8).

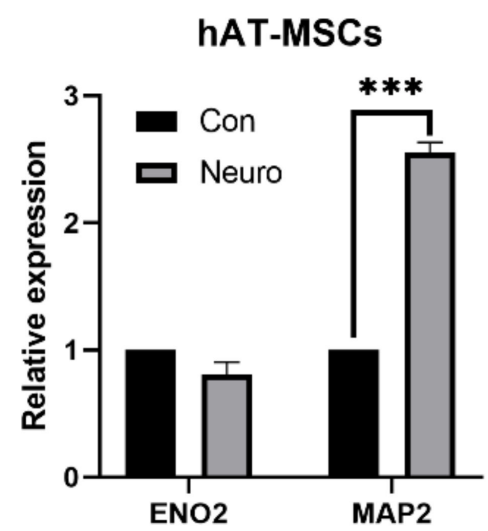

Figure 8. Expression of neural markers of human adipose tissue-derived mesenchymal stem cells (hAT-MSCs); ${ }^{* * *} p<0.001$; Con-control (non-induced sample), Neuro-neurodifferentiated sample; ENO2-neuron-specific enolase; MAP2-microtubule-associated protein 2. 


\subsubsection{Confocal Microscopy}

The expression of specific proteins of neuronal cells was examined by confocal microscopy. Immunofluorescent staining of differentiated cells proved the presence of specific neuronal markers, including neuron-specific enolase (ENO2) and microtubule-associated protein 2 (MAP2), in rMSCs and in hAT-MSCs (Figure 9).
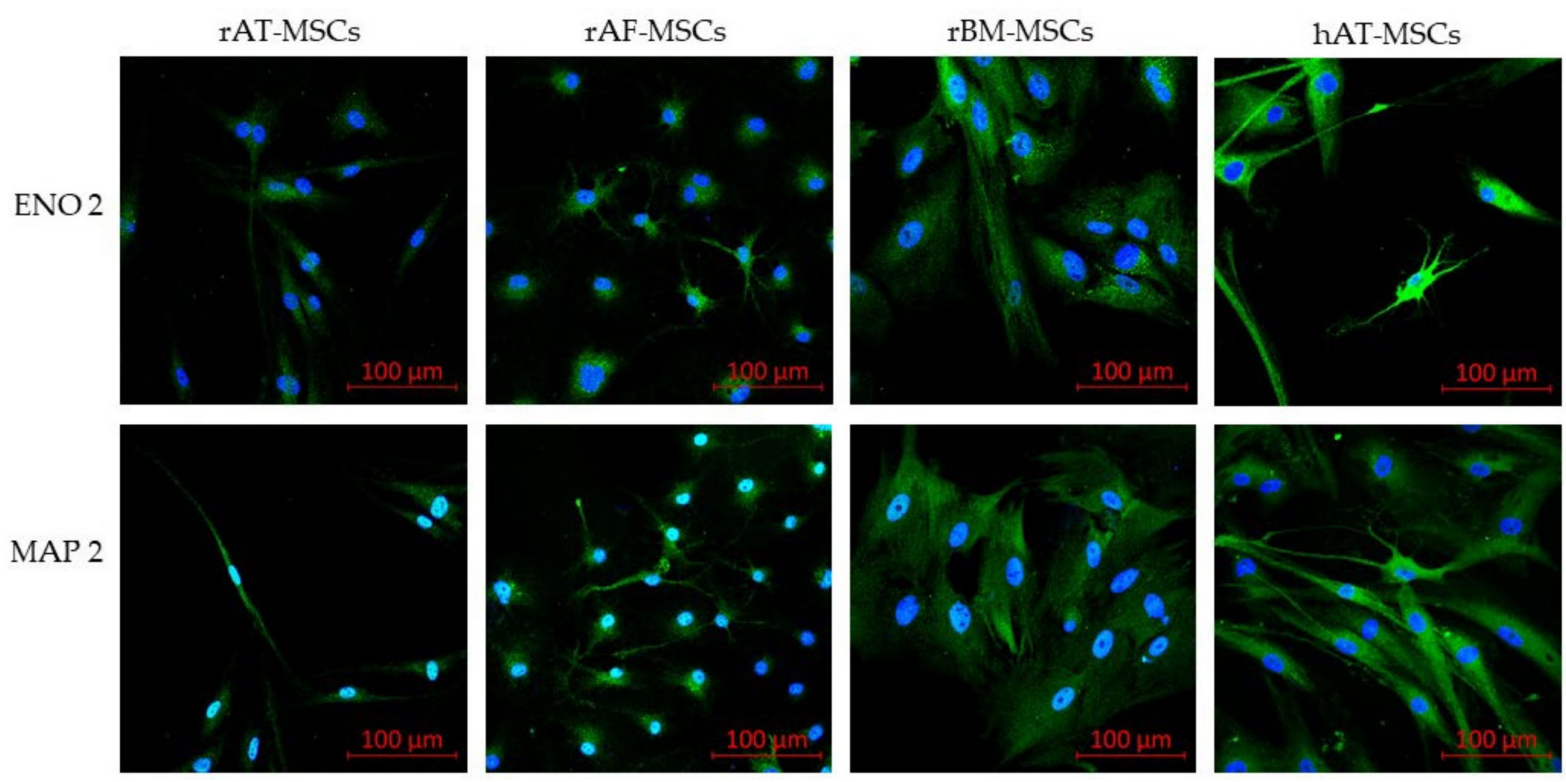

Figure 9. Confocal microscopy of specific neural markers. Neural markers ENO2 and MAP2 were highly expressed in all differentiated rabbit mesenchymal stem cells (rMSCs) as well as in human adipose tissue-derived mesenchymal stem cells (hAT-MSCs); rAT-MSCs—rabbit adipose tissue-derived mesenchymal stem cells; rAF-MSCs-rabbit amniotic fluid mesenchymal stem cells; rBM-MSCs—rabbit bone marrow mesenchymal stem cells; ENO2—neuron-specific enolase; MAP2-microtubule-associated protein 2; (Scale bars $=100 \mu \mathrm{m})$.

\section{Discussion}

Adipose tissue has come to the forefront of many studies, mainly due to its availability, easier isolation and higher cell yields, compared to the bone marrow. From a morphological point of view, these cells show a fibroblast-like shape, which changes during the culture from round to spindle-shaped. Similar cell morphology has been confirmed by many studies not only in rabbits [38,39] but also in other animal species, such as dogs [40], pigs [41], horse [42,43] and humans [44,45]. To monitor the rate of proliferation, we evaluated the doubling time of the cell population (PDT). We calculated the doubling time separately for each passage since P1 to P3. The mean PDT values for the individual passages were $38.97 \pm 14.05 \mathrm{~h}(\mathrm{P} 1), 36.26 \pm 8.58 \mathrm{~h}(\mathrm{P} 2)$ and $37.11 \pm 15.10 \mathrm{~h}(\mathrm{P} 3)$. From the results of the study [33], which reported PDT of rBM-MSCs for approximately 5 days, we concluded that rAT-MSCs proliferate significantly faster. Longer doubling time of the population was also reported for rAF-MSCs $(61.5 \pm 16.5 \mathrm{~h})$ [32]. Similar results for hAT-MSCs are described [46], and the results of their study contradict many claims about the effect of age on cell proliferative activity. When comparing the proliferation of the adipose tissue and the bone marrow stem cells, AT-MSCs showed a higher rate of expansion compared to BM-MSCs, which was confirmed in humans [47], but also in rats [48] and guinea pigs [49]. When comparing the PDT of human stem cells from different sources (placenta, bone marrow, umbilical cord, adipose tissue and amniotic fluid), the PDT of adipose stem cells was significantly lower compared to other sources, suggesting that these cells show the best in vitro proliferation activity [40].

The phenotype of human AT-MSCs is thoroughly characterized in various studies $[13,47]$. In general, these cells are defined as $\mathrm{CD} 29^{+}, \mathrm{CD}_{4}{ }^{+}, \mathrm{CD}^{+}{ }^{+}, \mathrm{CD}^{+}, \mathrm{CD}^{+} 5^{+}$, $\mathrm{CD} 34^{-}$and $\mathrm{CD} 45^{-}$. A similar phenotype, even though with small differences, was con- 
firmed also for rabbit AT-MSCs [39,50]. The positivity for CD49f marker (integrin $\alpha 6$ ), which is associated with cell pluripotency, is described by the present study in accordance with previous reports of [51-53], who claimed the expression of CD49f in MSCs from various sources. The present study contains the results confirming the expression of intracellular markers vimentin, desmin, $\alpha \mathrm{SMA}$, and the activity of aldehyde dehydrogenase (ALDH). The level of ALDH is currently used as a selection marker of the stem cells due to its relation to self-renewal and differentiation abilities [54,55]. The phenotypic profile was confirmed by flow cytometry and PCR methods on the mRNA level. The positive expression of surface and intracellular markers was confirmed by confocal microscopy in both rAT-MSCs and hAT-MSCs. Studies comparing the phenotype of human and rabbit AT-MSCs $[39,50,56]$ point out discrepancies in the expression of CD73, CD90 and CD105. Different clones of antibodies for these markers were tested on various rMSCs to distinguish the most appropriate antibodies for rabbit species. Selected markers were found highly positive using the digital droplet PCR technique. Thus, in the case of the unavailability of specific rabbit-antibodies, it is inevitable to quantify the expression applying other methods. According to the described results and previously published data, the use of other methods, such as RT-PCR or ddPCR, ought to be conducted in addition to flow cytometry for the purpose of appropriate phenotypic analysis of rabbit MSCs.

A difference between human BM-MSC and AT-MSC was observed in CD34 expression. While AT-MSCs weakly express this marker, in BM-MSC culture at the first passages, such expression was not confirmed [56,57]. On the other hand, an intracellular expression of CD34 was observed in the latter passages of human AT-MSCs [58]. Here, we did not observe any surface expression of CD34 in rAT-MSCs, although the intracellular expression of this marker was not analyzed. However, as we have already reported in our previous study [59], there is a lack of truly specific anti-rabbit CD34 antibodies that might be used for the immunological diagnostic methods. Nevertheless, also RT-PCR method did not reveal any CD34 expression, even if it would be expressed intracellularly. Moreover, the specificity of the PCR primers used to detect rabbit CD34 expression was validated in our previous studies $[33,59]$. Some studies also point to differences in the expression of intracellular markers $[11,60]$. The results indicate a difference in the expression of desmin, which was better expressed in BM-MSCs. Likewise, while desmin expression was positive in rabbit cells, human bone marrow stem cells did not express this marker. On the contrary, based on the results of our previous and present studies, we can state that this marker was more expressed in rAT-MSCs, rather than in rBM-MSCs, while we did not test this marker in hAT-MSCs. Despite the differences in isolation and culture, the immunophenotypic profile of rabbit AT-MSCs is relatively similar to the stem cells derived from the bone marrow and amniotic fluid, what was eventually confirmed by our previous [32,33] and the present studies. These results suggest that, although rabbit and human mesenchymal stem cells have similar differentiation potential, the expression of surface and intracellular markers differs among species. The expression of both surface and intracellular markers might be affected by in vitro culture and increasing passage number.

The expression of pluripotent markers in MSCs is controversial. While some authors [61,62] pointed out that AT-MSCs express embryonic stem cell genes, including OCT4, the findings of other authors did not confirm OCT4 expression in human [63] and murine [64] AT-MSCs. In our previous studies [31,33], we observed differences in the expression of pluripotent markers with respect to the source of stem cells. While rAF-MSCs expressed all selected pluripotency markers (NANOG, OCT4 and SOX2), rBM-MSCs expressed only the SOX2 marker. Compared to the results obtained in the present study, we assume that rAT-MSCs have better differentiation potential than rBM-MSCs, as we confirmed the expression of all mentioned markers of pluripotency by RT-PCR and confocal microscopy in those cells.

In general, hAT-MSCs are capable of differentiating into three cell lines: chondrocytes, osteocytes and adipocytes. The differentiation potential of stem cells is assessed in vitro using standard culture conditions in specific differentiation media. Commercial 
kits containing special media supplements, histological staining solutions or antibody panels are currently being designed to evaluate the differentiation of various cell lines. For more accurate analysis of differentiation, quantitative evaluation using lineage-specific gene markers is recommended [65]. In the present work, we differentiated rAT-MSCs into three baselines using commercially available differentiation kits. Based on the results of histological staining, we confirmed the successful differentiation of cells into osteogenic, adipogenic and chondrogenic lines (Figure A1; Appendix A). Our results are consistent with many studies on the differentiation potential of AT-MSCs, not only in rabbits but also in rats, guinea pigs, horses and also in humans [48,49,63-65]. In our previous studies, we also confirmed this differentiation potential on rBM-MSCs and rAF-MSCs [32,33].

In addition to basic three lineage differentiation, AT-MSCs have been shown to have neurogenic differentiation potential [66] and can also differentiate into cardiomyocytes and myocytes [67], endothelial cells [68] or hepatocytes [69]. The capability of AT-MSCs to differentiate into neuro-lineage possesses an outstanding potential for treating various neurological disorders. According to the literature, the changes in the morphology of AT-MSCs from fibroblast-like into neuron-like appearance recognized during short chemical induction, may be caused as a result of the cell shrinkage but not neural differentiation [24,25]. Similarly, histological staining of differentiated cells may not be conclusive evidence of neurodifferentiation. Hereby, morphological changes and histological staining alone should not be considered as successful differentiation, but the evaluation should be complemented by the detection of the expression of specific markers. There is a wide range of neuronal markers dependent on the neuronal lineage being investigated, including glial fibrillary acidic protein (GFAP), microtubule-associated protein 2 (MAP2), nestin, neuron-specific enolase (ENO2) or $\beta$-III-tubulin $[26,27]$. The expression of specific neuronal markers (ENO2, MAP2) was confirmed in the present work in all types of rabbit MSCs (AT-MSCs, BM-MSCs and AF-MSCs) as well as in hAT-MSCs, similarly as in other studies on human MSCs from different sources [70,71]. Based on our results, which correspond to the previously reported findings [72-74], we can state that stem cells isolated from the adipose tissue show several advantages compared to the bone marrow. Therefore, further examination of AT-MSCs is necessary to increase the quality and safety of clinical use in both human and veterinary medicine. The brief characteristics of rabbit and human mesenchymal stem cells isolated from different biological sources are listed in Table 7.

Table 7. Summary of characteristic features of rabbit and human mesenchymal stem cells from different tissues.

\begin{tabular}{|c|c|c|c|}
\hline & Adipose Tissue & Bone Marrow & Amniotic Fluid \\
\hline rMSCs & $\begin{array}{l}\text { PDT: approx. } 2 \text { days } \\
\text { - Phenotype: CD29+ } \mathrm{CD}^{+} 4^{+} ; \mathrm{CD} 73 \pm ; \\
\mathrm{CD} 90 \pm ; \mathrm{CD} 105 \pm ; \mathrm{CD} 34 \pm ; \mathrm{CD} 45- \\
\text { - SOX2 } \pm ; \mathrm{OCT} 4 \pm ; \mathrm{NANOG} \pm \\
\text { - Differentiation potential: adipo-genic, } \\
\text { osteogenic, chondrogenic, neurogenic } \\
{[17,34,39,58,60,75-79]}\end{array}$ & $\begin{array}{l}\text { - PDT: approx. } 5 \text { days } \\
\text { - Phenotype: } \mathrm{CD}^{+} 9^{+} ; \mathrm{CD} 44^{+} ; \mathrm{CD} 73^{+} ; \\
\mathrm{CD}^{+} ; \mathrm{CD} 105^{+} ; \mathrm{CD}^{+} 14^{-} ; \mathrm{CD} 34^{-}-\mathrm{CD}^{-} 5^{-} \\
\text {- SOX} 2 \pm \text { OCT } 4 \pm \text {; NANOG } \pm \\
\text { - Differentiation potential: adipogenic, } \\
\text { osteogenic, chondrogenic, neurogenic } \\
{[31,33,60,80,81]}\end{array}$ & $\begin{array}{l}\text { - PDT: approx. } 3 \text { days } \\
\text { - Phenotype: CD29+; CD } 44^{+} ; \mathrm{CD} 73 \pm ; \\
\text { CD90 } \pm ; \text { CD105 } \pm ; \text { CD } 34 \neg-; C D 45- \\
\text { - SOX2 } \pm ; \text { OCT } 4 \text {; NANOG } \pm \\
\text { - Differentiation potential: adipogenic, } \\
\text { osteogenic, chondrogenic, neurogenic, } \\
\text { cardiomyocytes } \\
\text { [31-33,82-85] }\end{array}$ \\
\hline hMSCs & 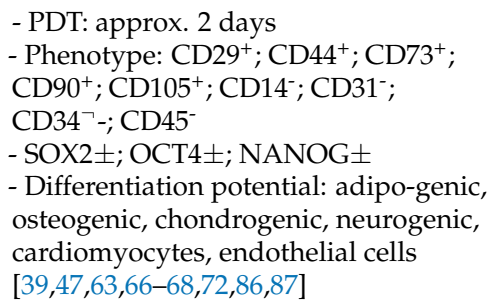 & 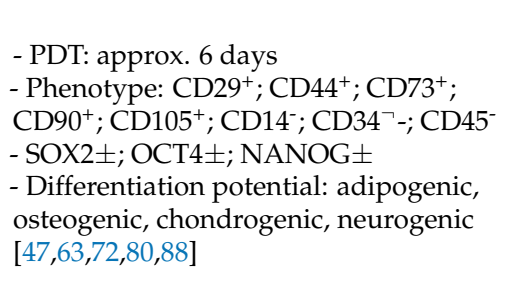 & 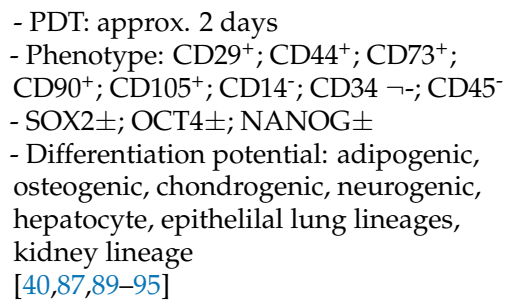 \\
\hline
\end{tabular}

rMSCs_-rabbit mesenchymal stem cells; hMSCs_-human mesenchymal stem cells; PDT- population doubling time; SOX2-sex determining region $\mathrm{Y}$-box 2; OCT4-octamer-binding transcription factor 4; +-positive expression; --negative expression; \pm - expression differs among studies. 


\section{Conclusions}

In summary, the present study was focused on properties of rabbit AT-MSCs. Obtained results suggest high similarity between rabbit AT-MSCs and human AT-MSCs. Moreover, it suggests the need for the assessment of marker expression at the mRNA level. The combination of immunostaining and PCR methods resulted in confirmation of positive expression of surface and intracellular markers (CD29, CD44, CD49f, CD73, CD90, CD105, vimentin, desmin, $\alpha$-SMA and ALDH). In addition, the expression of pluripotent markers (NANOG, OCT4 and SOX2) was confirmed. Based on these findings we can point out that successful neurodifferentiation was induced in rMSCs culture, which was proved by the presence of specific neuronal markers (ENO2 and MAP2). In conclusion, further analyses of rAT-MSCs are required in order to provide additional characterization of these cells intended for both clinical application and cryopreservation. AT-MSCs, cryostored in a gene bank, may serve as a valuable genetic source of breeds threatened with extinction.

Author Contributions: M.T. (Mária Tirpáková): Conceptualization, methodology, formal analysis, investigation, data curation, writing — original draft preparation, writing—review and editing. J.V.: methodology, formal analysis, investigation, resources, data curation, writing - review and editing, supervision, project administration, funding acquisition. A.S.: investigation, writing-review and editing. A.B.: investigation, writing-review and editing. M.T. (Marián Tomka): methodology, formal analysis, investigation, writing-review and editing. M.B.: methodology, formal analysis, investigation, data curation. A.M.: writing-review and editing. P.C.: writing-review and editing, supervision, project administration, funding acquisition. All authors have read and agreed to the published version of the manuscript.

Funding: This research was funded by the Slovak Research and Development Agency, grant numbers APVV-17-0124; APVV-18-0146 and by the Scientific Grant Agency of the Ministry of Education, Science, Research and Sport of the Slovak Republic and Slovak Academy of Science, grant number VEGA 1/0160/18 and VEGA 1/0049/19.

Institutional Review Board Statement: The study was conducted according to the guidelines of the Declaration of Helsinki, and approved by the Ministry of Agriculture and Rural Development of the Slovak Republic no. SK U 18016 (31.11.2016) in accordance with the ethical guidelines presented in Slovak Animal Protection Regulation (RD 377/12).

Informed Consent Statement: Not applicable.

Data Availability Statement: The data presented in this study are available in the article.

Conflicts of Interest: The authors declare no conflict of interest.

\section{Appendix A}

\section{Differentiation Assays}

To evaluate the multipotent character of rabbit adipose tissue-derived mesenchymal stem cells (rAT-MSCs), cells were differentiated into three basic lineages (adipogenic, chondrogenic and osteogenic) using standard induction media. Differentiation into adipogenic, chondrogenic and osteogenic lineages was performed in accordance with the manufacturer's instructions of commercially available kits (StemPro ${ }^{\circledR}$ Adipogenesis, StemPro ${ }^{\circledR}$ Chondrogenesis, StemPro ${ }^{\circledR}$ Osteogenesis; Thermo Fisher Scientific). Histological staining was used to evaluate the differential potential, as described in our previous studies [32,33]. Positive staining of proteoglycan deposits with Safranin-O confirmed chondrogenesis (Figure A1D). Stained lipid droplets in the cytoplasm using Oil-Red-O confirmed adipogenic differentiation (Figure A1E). Successful osteogenesis was verified by the detection of calcium aggregates (Figure A1F) stained with Alizarin-Red-S. As a control, non-induced cells were exposed to the staining with the appropriate dyes in recommended time intervals (Figure A1A-C). 

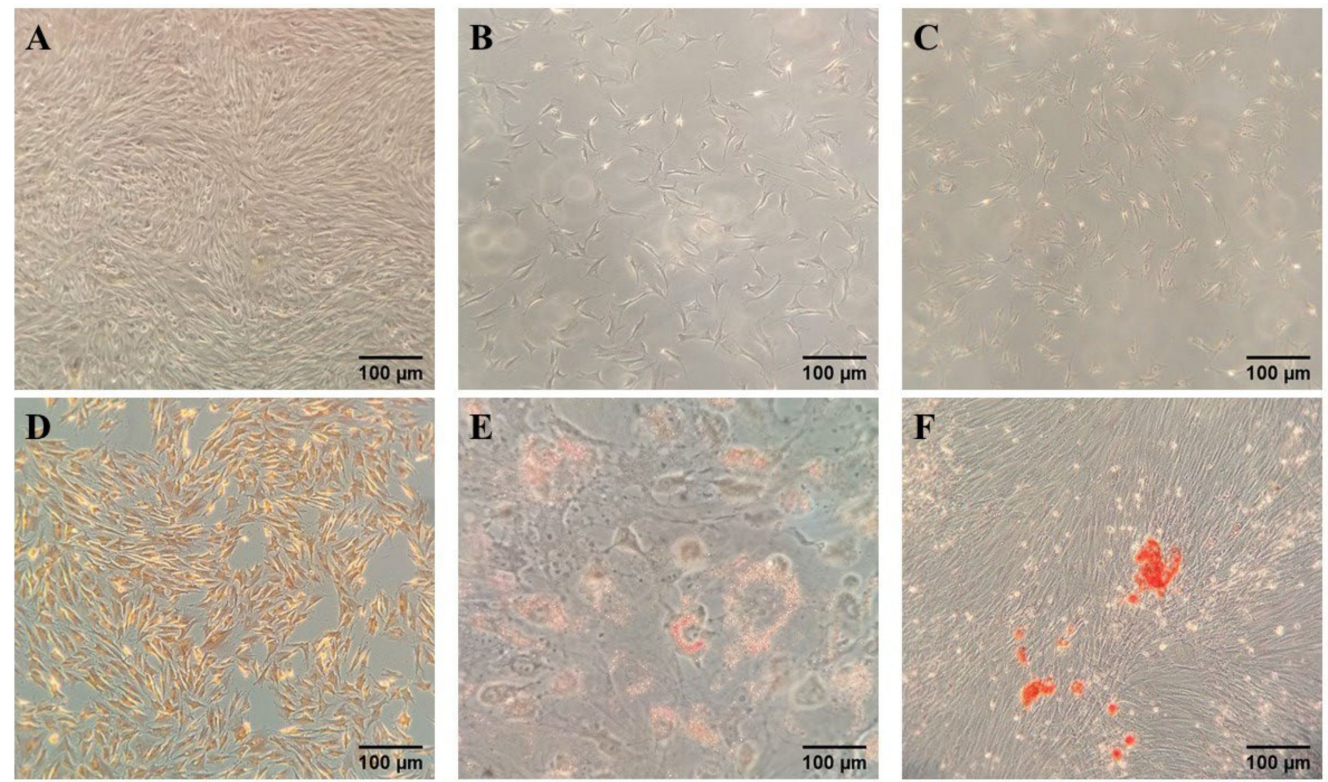

Figure A1. Histological staining of rAT-MSCs. (A-C)—Non-differenced cells remained unstained; (D)—deposits of proteoglycan in the differentiation-induced sample are stained with Safranin-O; (E)-lipid drops are stained red by Oil-Red$\mathrm{O}$; (F)—red dye Alizarin-Red-S identifies accumulation of calcium aggregates (Scale bars $=100 \mu \mathrm{m}$ ).

\section{References}

1. Seo, Y.; Shin, T.-H.; Kim, H.-S. Current Strategies to Enhance Adipose Stem Cell Function: An Update. Int. J. Mol. Sci. 2019, $20,3827$. [CrossRef]

2. Krueger, T.E.G.; Thorek, D.L.J.; Denmeade, S.R.; Isaacs, J.T.; Brennen, W.N. Concise Review: Mesenchymal Stem Cell-Based Drug Delivery: The Good, the Bad, the Ugly, and the Promise. Stem Cells Transl. Med. 2018, 7, 651-663. [CrossRef] [PubMed]

3. Sultana, T.; Lee, S.; Yoon, H.-Y.; Lee, J.I. Current Status of Canine Umbilical Cord Blood-Derived Mesenchymal Stem Cells in Veterinary Medicine. Stem Cells Int. 2018, 2018, 1-14. [CrossRef] [PubMed]

4. Harris, D.T. Banking of Adipose- and Cord Tissue-Derived Stem Cells: Technical and Regulatory Issues. Adv. Exp. Med. Biol. 2016, 951, 147-154. [CrossRef] [PubMed]

5. Yong, K.W.; Choi, J.R.; Wan Safwani, W.K.Z. Biobanking of human mesenchymal stem cells: Future strategy to facilitate clinical applications. In Biobanking and Cryopreservation of Stem Cells; Karimi-Busheri, F., Weinfeld, M., Eds.; Advances in Experimental Medicine and Biology; Springer International Publishing: Cham, Switzerland, 2016; pp. 99-110. [CrossRef]

6. Dayem, A.A.; Bin Lee, S.; Kim, K.; Lim, K.M.; Jeon, T.-I.; Seok, J.; Cho, A.S.-G. Production of Mesenchymal Stem Cells Through Stem Cell Reprogramming. Int. J. Mol. Sci. 2019, 20, 1922. [CrossRef] [PubMed]

7. Majka, M.; Sułkowski, M.; Badyra, B.; Musiałek, P. Concise Review: Mesenchymal Stem Cells in Cardiovascular Regeneration: Emerging Research Directions and Clinical Applications. Stem Cells Transl. Med. 2017, 6, 1859-1867. [CrossRef] [PubMed]

8. Sullivan, M.O.; Gordon-Evans, W.J.; Fredericks, L.P.; Kiefer, K.; Conzemius, M.G.; Griffon, D.J. Comparison of Mesenchymal Stem Cell Surface Markers from Bone Marrow Aspirates and Adipose Stromal Vascular Fraction Sites. Front. Veter. Sci. $2016,2,82$. [CrossRef]

9. Strem, B.M.; Hicok, K.C.; Zhu, M.; Wulur, I.; Alfonso, Z.; E Schreiber, R.; Fraser, J.K.; Hedrick, M.H. Multipotential differentiation of adipose tissue-derived stem cells. Keio J. Med. 2005, 54, 132-141. [CrossRef] [PubMed]

10. Moore, T.J.; Abrahamse, H. Neuronal Differentiation of Adipose Derived Stem Cells: Progress So Far. Int. J. Photoenergy 2014, 2014, 1-8. [CrossRef]

11. Lee, T.-C.; Lee, T.-H.; Huang, Y.-H.; Chang, N.-K.; Lin, Y.-J.; Chien, P.-W.C.; Yang, W.-H.; Lin, M.H.-C. Comparison of Surface Markers between Human and Rabbit Mesenchymal Stem Cells. PLoS ONE 2014, 9, e111390. [CrossRef]

12. Screven, R.; Kenyon, E.; Myers, M.J.; Yancy, H.F.; Skasko, M.; Boxer, L.; Bigley, E.C., III; Borjesson, D.L.; Zhu, M. Immunophenotype and Gene Expression Profile of Mesenchymal Stem Cells Derived from Canine Adipose Tissue and Bone Marrow. Vet. Immunol. Immunopathol. 2014, 161, 21-31. [CrossRef] [PubMed]

13. Kocan, B.; Maziarz, A.; Tabarkiewicz, J.; Ochiya, T.; Banaś-Ząbczyk, A. Trophic Activity and Phenotype of Adipose Tissue-Derived Mesenchymal Stem Cells as a Background of Their Regenerative Potential. Stem Cells Int. 2017, 2017, 1-13. [CrossRef] [PubMed]

14. González-Garza, M.T.; Cruz-Vega, D.E.; Cárdenas-Lopez, A.; De La Rosa, R.M.; Moreno-Cuevas, J.E. Comparing stemness gene expression between stem cell subpopulations from peripheral blood and adipose tissue. Am. J. Stem Cells 2018, 7, 38-47. [PubMed]

15. Bailey, A.M.; Kapur, S.; Katz, A.J. Characterization of Adipose-Derived Stem Cells: An Update. Curr. Stem Cell Res. Ther. 2010, 5 , 95-102. [CrossRef] 
16. Mizuno, H.; Tobita, M.; Uysal, A.C. Concise Review: Adipose-Derived Stem Cells as a Novel Tool for Future Regenerative Medicine. Stem Cells 2012, 30, 804-810. [CrossRef]

17. Bourin, P.; Bunnell, B.A.; Casteilla, L.; Dominici, M.; Katz, A.J.; March, K.L.; Redl, H.; Rubin, J.P.; Yoshimura, K.; Gimble, J.M. Stromal cells from the adipose tissue-derived stromal vascular fraction and culture expanded adipose tissue-derived stromal/stem cells: A joint statement of the International Federation for Adipose Therapeutics and Science (IFATS) and the International Society for Cellular Therapy (ISCT). Cytotherapy 2013, 15, 641-648. [CrossRef]

18. Bajek, A.; Gurtowska, N.; Olkowska, J.; Maj, M.; Kaźmierski, Ł.; Bodnar, M.; Marszałek, A.; Dębski, R.; Drewa, T. Does the Harvesting Technique Affect the Properties of Adipose-Derived Stem Cells?-The Comparative Biological Characterization. J. Cell. Biochem. 2017, 118, 1097-1107. [CrossRef]

19. Si, Z.; Wang, X.; Sun, C.; Kang, Y.; Xu, J.; Wang, X.; Hui, Y. Adipose-derived stem cells: Sources, potency, and implications for regenerative therapies. Biomed. Pharmacother. 2019, 114, 108765. [CrossRef]

20. Anwer, A.G.; Gosnell, M.E.; Perinchery, S.M.; Inglis, D.W.; Goldys, E.M. Visible 532 nm laser irradiation of human adipose tissue-derived stem cells: Effect on proliferation rates, mitochondria membrane potential and autofluorescence. Lasers Surg. Med. 2012, 44, 769-778. [CrossRef]

21. Mvula, B.; Moore, T.J.; Abrahamse, H. Effect of low-level laser irradiation and epidermal growth factor on adult human adipose-derived stem cells. Lasers Med. Sci. 2010, 25, 33-39. [CrossRef]

22. De Villiers, J.A.; Houreld, N.N.; Abrahamse, H. Influence of Low Intensity Laser Irradiation on Isolated Human Adipose Derived Stem Cells Over 72 Hours and Their Differentiation Potential into Smooth Muscle Cells Using Retinoic Acid. Stem Cell Rev. Rep. 2011, 7, 869-882. [CrossRef]

23. Muller, S.; Abrahamse, H.; Ndlovu, L.; Houreld, N.N. Fluence and Wavelength of Low Intensity Laser Irradiation Affect Activity and Proliferation of Human Adipose Derived Stem Cells: Peer Reviewed Original Article. Med. Technol. SA 2010, $24,15-20$.

24. Neuhuber, B.; Gallo, G.; Howard, L.; Kostura, L.; Mackay, A.; Fischer, I. Reevaluation of in vitro differentiation protocols for bone marrow stromal cells: Disruption of actin cytoskeleton induces rapid morphological changes and mimics neuronal phenotype. J. Neurosci. Res. 2004, 77, 192-204. [CrossRef]

25. Bertani, N.; Malatesta, P.; Volpi, G.; Sonego, P.; Perris, R. Neurogenic potential of human mesenchymal stem cells revisited: Analysis by immunostaining, time-lapse video and microarray. J. Cell Sci. 2005, 118, 3925-3936. [CrossRef]

26. Pavlova, G.; Lopatina, T.; Kalinina, N.; Rybalkina, E.; Parfyonova, Y.; Tkachuk, V.; Revishchin, A. In vitro neuronal induction of adipose-derived stem cells and their fate after transplantation into injured mouse brain. Curr. Med. Chem. 2012, 19, 5170-5177. [CrossRef]

27. Cardozo, A.J.; Gómez, D.E.; Argibay, P.F. Neurogenic differentiation of human adipose-derived stem cells: Relevance of different signaling molecules, transcription factors, and key marker genes. Gene 2012, 511, 427-436. [CrossRef] [PubMed]

28. Intawicha, P.; Ou, Y.-W.; Lo, N.-W.; Zhang, S.-C.; Chen, Y.-Z.; Lin, T.-A.; Su, H.-L.; Guu, H.-F.; Chen, M.-J.; Lee, K.-H.; et al. Characterization of Embryonic Stem Cell Lines Derived from New Zealand White Rabbit Embryos. Cloning Stem Cells 2009, 11, 27-38. [CrossRef]

29. Calasans-Maia, M.D.; Monteiro, M.L.; Áscoli, F.O.; Granjeiro, J.M. The rabbit as an animal model for experimental surgery. Acta Cir. Bras. 2009, 24, 325-328. [CrossRef] [PubMed]

30. Thomas, B.S.; Bhat, K.M.; Mapara, M. Rabbit as an animal model for experimental research. Dent. Res. J. 2012, 9, 111-118. [CrossRef] [PubMed]

31. Kovac, M.; Vasicek, J.; Kulikova, B.; Bauer, M.; Curlej, J.; Balazi, A.; Chrenek, P. Different RNA and protein expression of surface markers in rabbit amniotic fluid-derived mesenchymal stem cells. Biotechnol. Prog. 2017, 33, 1601-1613. [CrossRef] [PubMed]

32. Kulikova, B.; Kovac, M.; Bauer, M.; Tomkova, M.; Olexikova, L.; Vasicek, J.; Balazi, A.; Makarevich, A.V.; Chrenek, P. Survivability of rabbit amniotic fluid-derived mesenchymal stem cells post slow-freezing or vitrification. Acta Histochem. 2019, 121, 491-499. [CrossRef] [PubMed]

33. Vašíček, J.; Kováč, M.; Baláži, A.; Kulíková, B.; Tomková, M.; Olexíková, L.; Čurlej, J.; Bauer, M.; Schnabl, S.; Hilgarth, M.; et al. Combined approach for characterization and quality assessment of rabbit bone marrow-derived mesenchymal stem cells intended for gene banking. New Biotechnol. 2020, 54, 1-12. [CrossRef]

34. Tomková, M.; Kulíková, B.; Vašíček, J.; Baláži, A.; Makarevič, A.; Chrenek, P. Effect of Different Culture Medium on Cultivation of Adipose Tissue Derived Stem Cells from Two Biological Sources. J. Microbiol. Biotechnol. Food Sci. 2018, 8, 798-801. [CrossRef]

35. Su, J.; Chen, X.; Huang, Y.; Li, W.; Li, J.; Cao, K.; Cao, G.; Zhang, L.; Li, F.; I Roberts, A.; et al. Phylogenetic distinction of iNOS and IDO function in mesenchymal stem cell-mediated immunosuppression in mammalian species. Cell Death Differ. 2014, 21, 388-396. [CrossRef] [PubMed]

36. Pfaffl, M.W. A new mathematical model for relative quantification in real-time RT-PCR. Nucleic Acids Res. 2001, 29, e45. [CrossRef] [PubMed]

37. Esfandiari, B.; Soliemani, M.; Kaviani, S.; Parivar, K. Rapid Neural Differentiation of Human Adipose Tissue-Derived Stem Cells Using NGF, Forskolin and BFGF. Biomed. Pharmacol. J. 2016, 9, 39. [CrossRef]

38. Gayathri, V.; Harikrishnan, V.; Mohanan, P.V. Integration of Rabbit Adipose Derived Mesenchymal Stem Cells to Hydroxyapatite Burr Hole Button Device for Bone Interface Regeneration. Int. J. Biomater. 2016, 2016, 1-9. [CrossRef] 
39. Zomer, H.D.; Roballo, K.C.; Lessa, T.B.; Bressan, F.F.; Gonçalves, N.N.; Meirelles, F.V.; Trentin, A.G.; Ambrósio, C.E. Distinct features of rabbit and human adipose-derived mesenchymal stem cells: Implications for biotechnology and translational research. Stem Cells Cloning Adv. Appl. 2018, 11, 43-54. [CrossRef]

40. Zhan, X.-S.; El-Ashram, S.; Luo, D.-Z.; Luo, H.-N.; Wang, B.-Y.; Chen, S.-F.; Bai, Y.-S.; Chen, Z.-S.; Liu, C.-Y.; Ji, H.-Q. A Comparative Study of Biological Characteristics and Transcriptome Profiles of Mesenchymal Stem Cells from Different Canine Tissues. Int. J. Mol. Sci. 2019, 20, 1485. [CrossRef]

41. Arrizabalaga, J.H.; Nollert, M.U. Properties of porcine adipose-derived stem cells and their applications in preclinical models. Adipocyte 2017, 6, 217-223. [CrossRef]

42. Bourebaba, L.; Michalak, I.; Baouche, M.; Kucharczyk, K.; Marycz, K. Cladophora glomerata methanolic extract promotes chondrogenic gene expression and cartilage phenotype differentiation in equine adipose-derived mesenchymal stromal stem cells affected by metabolic syndrome. Stem Cell Res. Ther. 2019, 10, 1-20. [CrossRef]

43. Elashry, M.I.; Gegnaw, S.T.; Klymiuk, M.C.; Wenisch, S.; Arnhold, S. Influence of mechanical fluid shear stress on the osteogenic differentiation protocols for Equine adipose tissue-derived mesenchymal stem cells. Acta Histochem. 2019, 121, 344-353. [CrossRef] [PubMed]

44. Palumbo, P.; Lombardi, F.; Siragusa, G.; Cifone, M.G.; Cinque, B.; Giuliani, M. Methods of Isolation, Characterization and Expansion of Human Adipose-Derived Stem Cells (ASCs): An Overview. Int. J. Mol. Sci. 2018, 19, 1897. [CrossRef] [PubMed]

45. Machado, A.K.; Homrich, S.G.; Rodrigues, C.C.R.; Azzolin, V.F.; Duarte, M.M.M.F.; Pillar, D.M.; Lenz, L.S.; Unfer, T.C.; De Souza, D.V.; Da Cruz, I.B.M. Human adipose-derived stem cells obtained from lipoaspirates are highly susceptible to hydrogen peroxide mediated cytogenotoxicity. Arch. Biosci. Health 2019, 1, 11-28. [CrossRef]

46. Kawagishi-Hotta, M.; Hasegawa, S.; Igarashi, T.; Yamada, T.; Takahashi, M.; Numata, S.; Kobayashi, T.; Iwata, Y.; Arima, M.; Yamamoto, N.; et al. Enhancement of individual differences in proliferation and differentiation potentials of aged human adipose-derived stem cells. Regen. Ther. 2017, 6, 29-40. [CrossRef]

47. Kern, S.; Eichler, H.; Stoeve, J.; Klüter, H.; Bieback, K. Comparative Analysis of Mesenchymal Stem Cells from Bone Marrow, Umbilical Cord Blood, or Adipose Tissue. Stem Cells 2006, 24, 1294-1301. [CrossRef] [PubMed]

48. Baghban, E.M.R.; Mardpour, S.; Ebrahimi, M. Growth Kinetics and in Vitro Aging of Mesenchymal Stem Cells Isolated from Rat Adipose versus Bone Marrow Tissues. Iran. J. Vet. Surg. 2008, 3, 9-20.

49. Aliborzi, G.; Vahdati, A.; Mehrabani, D.; Hosseini, S.E.; Tamadon, A. Isolation, Characterization and Growth Kinetic Comparison of Bone Marrow and Adipose Tissue Mesenchymal Stem Cells of Guinea Pig. Int. J. Stem Cells 2016, 9, 115-123. [CrossRef]

50. Martínez-Lorenzo, M.J.; Royo-Cañas, M.; Alegre-Aguarón, E.; Desportes, P.; Castiella, T.; García-Álvarez, F.; Larrad, L. Phenotype and Chondrogenic Differentiation of Mesenchymal Cells from Adipose Tissue of Different Species. J. Orthop. Res. 2009, 27, 1499-1507. [CrossRef]

51. Lv, F.-J.; Tuan, R.S.; Cheung, K.M.; Leung, V.Y. Concise Review: The Surface Markers and Identity of Human Mesenchymal Stem Cells. Stem Cells 2014, 32, 1408-1419. [CrossRef] [PubMed]

52. Lee, R.H.; Seo, M.J.; Pulin, A.A.; Gregory, C.A.; Ylostalo, J.; Prockop, D.J. The CD34-like protein PODXL and $\alpha 6$-integrin (CD49f) identify early progenitor MSCs with increased clonogenicity and migration to infarcted heart in mice. Blood 2009, 113, 816-826. [CrossRef] [PubMed]

53. Yu, K.-R.; Yang, S.-R.; Jung, J.-W.; Kim, H.; Ko, K.; Han, D.W.; Park, S.-B.; Choi, S.W.; Kang, S.-K.; Scholer, H.; et al. CD49f Enhances Multipotency and Maintains Stemness Through the Direct Regulation of OCT4 and SOX2. Stem Cells 2012, 30, 876-887. [CrossRef] [PubMed]

54. Vassalli, G. Aldehyde Dehydrogenases: Not Just Markers, but Functional Regulators of Stem Cells. Stem Cells Int. 2019, 2019, 1-15. [CrossRef]

55. Itoh, H.; Nishikawa, S.; Haraguchi, T.; Arikawa, Y.; Eto, S.; Hiyama, M.; Iseri, T.; Itoh, Y.; Nakaichi, M.; Sakai, Y.; et al. Aldehyde dehydrogenase activity helps identify a subpopulation of murine adipose-derived stem cells with enhanced adipogenic and osteogenic differentiation potential. World J. Stem Cells 2017, 9, 179-186. [CrossRef] [PubMed]

56. Tsekouras, A.; Mantas, D.; Tsilimigras, I.D.; Moris, D.; Kontos, M.; Zografos, C.G. Comparison of the Viability and Yield of Adipose-Derived Stem Cells (ASCs) from Different Donor Areas. In Vivo 2017, 31, 1229-1234. [CrossRef]

57. Zampar, A.G.; Junior, J.A.F.; Orellana, M.D.; Caruso, S.R.; Fernandes, T.R.; Gomes, R.; Aragon, D.C.; De Santis, G.C.; Covas, D.T. Analysis of Adipose-Derived Stem Cells from Different Donor Areas and Their Influence on Fibroblasts In Vitro. Aesthetic Plast. Surg. 2020, 44, 971-978. [CrossRef]

58. Mitterberger, M.C.; Lechner, S.; Mattesich, M.; Kaiser, A.; Probst, D.; Wenger, N.; Pierer, G.; Zwerschke, W. DLK1 (PREF1) Is a Negative Regulator of Adipogenesis in CD105+/CD90+/CD34+/CD31-/FABP4- Adipose-Derived Stromal Cells from Subcutaneous Abdominal Fat Pats of Adult Women. Stem Cell Res. 2012, 9, 35-48. [CrossRef]

59. Vašíček, J.; Shehata, M.; Schnabl, S.; Hilgarth, M.; Hubmann, R.; Jäger, U.; Bauer, M.; Chrenek, P. Critical assessment of the efficiency of CD34 and CD133 antibodies for enrichment of rabbit hematopoietic stem cells. Biotechnol. Prog. 2018, 34, 1278-1289. [CrossRef]

60. Yaszemski, A.; Rooney, G.E.; Windebank, A.J. Characterization of Rabbit Mesenchymal Stem Cells. In Experimental Biology 2011 Meeting Abstracts; Wiley: Washington, MD, USA, 2011. 
61. Echeverry, D.M.; Rojas, D.M.; Aguilera, C.J.; Veraguas, D.M.; Cabezas, J.G.; Rodríguez-Álvarez, L.; Castro, F.O. Differentiation and multipotential characteristics of mesenchymal stem cells derived from adipose tissue of an endangered wild cat (Leopardus guigna). Austral. J. Veter. Sci. 2019, 51, 17-26. [CrossRef]

62. Peroni, D.; Scambi, I.; Pasini, A.; Lisi, V.; Bifari, F.; Krampera, M.; Rigotti, G.; Sbarbati, A.; Galiè, M. Stem molecular signature of adipose-derived stromal cells. Exp. Cell Res. 2008, 314, 603-615. [CrossRef]

63. Heo, J.S.; Choi, Y.; Kim, H.-S.; Kim, H.O. Comparison of Molecular Profiles of Human Mesenchymal Stem Cells Derived from Bone Marrow, Umbilical Cord Blood, Placenta and Adipose Tissue. Int. J. Mol. Med. 2016, 37, 115-125. [CrossRef] [PubMed]

64. Case, J.; Horvath, T.L.; Ballas, C.B.; March, K.L.; Srour, E.F. In vitro clonal analysis of murine pluripotent stem cells isolated from skeletal muscle and adipose stromal cells. Exp. Hematol. 2008, 36, 224-234. [CrossRef] [PubMed]

65. Almalki, S.G.; Agrawal, D.K. Key transcription factors in the differentiation of mesenchymal stem cells. Differentiation 2016, 92, 41-51. [CrossRef] [PubMed]

66. Radhakrishnan, S.; Trentz, O.A.; Reddy, M.S.; Rela, M.; Kandasamy, M.; Sellathamby, S. In vitro transdifferentiation of human adipose tissue-derived stem cells to neural lineage cells-A stage-specific incidence. Adipocyte 2019, 8, 164-177. [CrossRef]

67. Hasani, S.; Javeri, A.; Asadi, A.; Taha, M.F. Cardiac Differentiation of Adipose Tissue-Derived Stem Cells Is Driven by BMP4 and bFGF but Counteracted by 5-Azacytidine and Valproic Acid. Cell J. 2019, 22, 273-282.

68. Al-Ghadban, S.; Bunnell, B.A. Adipose Tissue-Derived Stem Cells: Immunomodulatory Effects and Therapeutic Potential. Physiology 2020, 35, 125-133. [CrossRef]

69. Lu, T.; Pei, W.; Wang, K.; Zhang, S.; Chen, F.; Wu, Y.; Guan, W. In Vitro Culture and Biological Properties of Broiler Adipose-derived Stem Cells. Exp. Ther. Med. 2018, 16, 2399-2407. [CrossRef]

70. Kruminis-Kaszkiel, E.; Osowski, A.; Bejer-Oleńska, E.; Dziekoński, M.; Wojtkiewicz, J. Differentiation of Human Mesenchymal Stem Cells from Wharton's Jelly Towards Neural Stem Cells Using a Feasible and Repeatable Protocol. Cells 2020, 9, 739. [CrossRef]

71. Cortés-Medina, L.V.; Pasantes-Morales, H.; Aguilera-Castrejon, A.; Picones, A.; Lara-Figueroa, C.O.; Luis, E.; Montesinos, J.J.; Cortés-Morales, V.A.; Ruiz, M.P.D.L.R.; Hernández-Estévez, E.; et al. Neuronal Transdifferentiation Potential of Human Mesenchymal Stem Cells from Neonatal and Adult Sources by a Small Molecule Cocktail. Stem Cells Int. 2019, 2019, 1-13. [CrossRef]

72. Urrutia, D.N.; Caviedes, P.; Mardones, R.; Minguell, J.J.; Vega-Letter, A.M.; Jofre, C.M. Comparative study of the neural differentiation capacity of mesenchymal stromal cells from different tissue sources: An approach for their use in neural regeneration therapies. PLoS ONE 2019, 14, e0213032. [CrossRef]

73. Kozlowska, U.; Krawczenko, A.; Futoma, K.; Jurek, T.; Rorat, M.; Patrzalek, D.; Klimczak, A. Similarities and differences between mesenchymal stem/progenitor cells derived from various human tissues. World J. Stem Cells 2019, 11, 347-374. [CrossRef] [PubMed]

74. Musina, R.A.; Bekchanova, E.S.; Sukhikh, G.T. Comparison of Mesenchymal Stem Cells Obtained from Different Human Tissues. Bull. Exp. Biol. Med. 2005, 139, 504-509. [CrossRef]

75. Forghani, A.; Koduru, S.V.; Chen, C.; Leberfinger, A.N.; Ravnic, D.J.; Hayes, D.J. Differentiation of Adipose Tissue-Derived CD34+/CD31- Cells into Endothelial Cells In Vitro. Regen. Eng. Transl. Med. 2020, 6, 101-110. [CrossRef] [PubMed]

76. Baptista, L.S. Adipose stromal/stem cells in regenerative medicine: Potentials and limitations. World J. Stem Cells 2020, 12, 1-7. [CrossRef] [PubMed]

77. Lisini, D.; Nava, S.; Pogliani, S.; Avanzini, M.; Lenta, E.; Bedini, G.; Mantelli, M.; Pecciarini, L.; Croce, S.; Boncoraglio, G.; et al. Adipose tissue-derived mesenchymal stromal cells for clinical application: An efficient isolation approach. Curr. Res. Transl. Med. 2019, 67, 20-27. [CrossRef] [PubMed]

78. Adolfsson, E.; Helenius, G.; Friberg, Ö.; Samano, N.; Frøbert, O.; Johansson, K. Bone marrow- and adipose tissue-derived mesenchymal stem cells from donors with coronary artery disease; growth, yield, gene expression and the effect of oxygen concentration. Scand. J. Clin. Lab. Investig. 2020, 80, 318-326. [CrossRef]

79. Patrikoski, M.; Mannerström, B.; Miettinen, S. Perspectives for Clinical Translation of Adipose Stromal/Stem Cells. Stem Cells Int. 2019, 2019, 1-21. [CrossRef]

80. Tan, S.-L.; Ahmad, T.S.; Selvaratnam, L.; Kamarul, T. Isolation, characterization and the multi-lineage differentiation potential of rabbit bone marrow-derived mesenchymal stem cells. J. Anat. 2013, 222, 437-450. [CrossRef]

81. Cong, Z.; Lin, J.-B.; Jiang, H.-X.; Lin, W.-B.; Gao, J.-T.; Gao, M.-M.; Wu, B.-W.; Feng, B.; Cheng, N.-N.; Huang, G.; et al. Comparison and Optimization: Different Medium and a Novel Scheme for Rabbit Bone Marrow Mesenchymal Stem Cells Culture. Res. Square 2020. [CrossRef]

82. Borghesi, J.; Mario, L.C.; Carreira, A.C.O.; Miglino, M.A.; Favaron, P.O. Phenotype and multipotency of rabbit (Oryctolagus cuniculus) amniotic stem cells. Stem Cell Res. Ther. 2017, 8, 27. [CrossRef]

83. Kováč, M.; Kulíková, B.; Vašíček, J.; Chrenek, P. Cryopreservation of Amniotic Fluid Stem Cells Derived from Zobor Rabbit. Slovak J. Anim. Sci. 2016, 2016, 62-67.

84. Slamečka, J.J.; Chrenek, P. Rabbit Amniotic Fluid as a Potential Alternative Source of Broadly Multipotent Stem Cells. Slovak J. Anim. Sci. 2013, 2013, 11-15.

85. Jiang, S.; Zhang, S. Differentiation of cardiomyocytes from amniotic fluid-derived mesenchymal stem cells by combined induction with transforming growth factor $\beta 1$ and 5-azacytidine. Mol. Med. Rep. 2017, 16, 5887-5893. [CrossRef] [PubMed] 
86. Debnath, T.; Chelluri, L.K. Standardization and quality assessment for clinical grade mesenchymal stem cells from human adipose tissue. Hematol. Transfus. Cell Ther. 2019, 41, 7-16. [CrossRef] [PubMed]

87. Bajek, A.; Olkowska, J.; Walentowicz-Sadłecka, M.; Sadłecki, P.; Grabiec, M.; Porowinska, D.; Drewa, T.; Roszkowski, K. Human Adipose-Derived and Amniotic Fluid-Derived Stem Cells: A Preliminary In Vitro Study Comparing Myogenic Differentiation Capability. Med. Sci. Monit. 2018, 24, 1733-1741. [CrossRef] [PubMed]

88. Dominici, M.; Le Blanc, K.; Mueller, I.; Slaper-Cortenbach, I.; Marini, F.C.; Krause, D.S.; Deans, R.J.; Keating, A.; Prockop, D.J.; Horwitz, E.M. Minimal criteria for defining multipotent mesenchymal stromal cells. The International Society for Cellular Therapy position statement. Cytotherapy 2006, 8, 315-317. [CrossRef] [PubMed]

89. Dekoninck, P.; Toelen, J.; Roubliova, X.; Carter, S.; Pozzobon, M.; Russo, F.M.; Richter, J.; Vandersloten, P.-J.; Verbeken, E.; De Coppi, P.; et al. The use of human amniotic fluid stem cells as an adjunct to promote pulmonary development in a rabbit model for congenital diaphragmatic hernia. Prenat. Diagn. 2015, 35, 833-840. [CrossRef] [PubMed]

90. Roubelakis, M.G.; Pappa, K.I.; Bitsika, V.; Zagoura, D.; Vlahou, A.; Papadaki, H.A.; Antsaklis, A.; Anagnou, N.P. Molecular and Proteomic Characterization of Human Mesenchymal Stem Cells Derived from Amniotic Fluid: Comparison to Bone Marrow Mesenchymal Stem Cells. Stem Cells Dev. 2007, 16, 931-952. [CrossRef]

91. Fei, X.; Jiang, S.; Zhang, S.; Li, Y.; Ge, J.; He, B.; Goldstein, S.; Ruiz, G. Isolation, Culture, and Identification of Amniotic Fluid-Derived Mesenchymal Stem Cells. Cell Biophys. 2013, 67, 689-694. [CrossRef]

92. Janz, F.D.L.; Debes, A.D.A.; Cavaglieri, R.D.C.; Duarte, S.A.; Romão, C.M.; Morón, A.F.; Zugaib, M.; Bydlowski, S.P. Evaluation of Distinct Freezing Methods and Cryoprotectants for Human Amniotic Fluid Stem Cells Cryopreservation. J. Biomed. Biotechnol. 2012, 2012, 1-10. [CrossRef]

93. Perin, L.; Giuliani, S.; Jin, D.; Sedrakyan, S.; Carraro, G.; Habibian, R.; Warburton, D.; Atala, A.; De Filippo, R.E. Renal differentiation of amniotic fluid stem cells. Cell Prolif. 2007, 40, 936-948. [CrossRef] [PubMed]

94. Gholizadeh-Ghalehaziz, S.; Farahzadi, R.; Fathi, E.; Pashaiasl, A.M. A Mini Overview of Isolation, Characterization and Application of Amniotic Fluid Stem Cells. Int. J. Stem Cells 2015, 8, 115-120. [CrossRef] [PubMed]

95. Kim, J.; Lee, Y.; Kim, H.; Hwang, K.J.; Kwon, H.C.; Kim, S.K.; Cho, D.J.; Kang, S.G.; You, J. Human amniotic fluid-derived stem cells have characteristics of multipotent stem cells. Cell Prolif. 2007, 40, 75-90. [CrossRef] [PubMed] 